Florida International University FIU Digital Commons

$3-12-1981$

\title{
A study to adapt various sales forecasting methods for use by military club managers
}

Alfred J. Bender

Florida International University

DOI: $10.25148 /$ etd.FI14050495

Follow this and additional works at: https://digitalcommons.fiu.edu/etd

Part of the Hospitality Administration and Management Commons

\section{Recommended Citation}

Bender, Alfred J., "A study to adapt various sales forecasting methods for use by military club managers" (1981). FIU Electronic Theses and Dissertations. 1498.

https://digitalcommons.fiu.edu/etd/1498 
A STUDY TO ADAPT VARIOUS SALES FORECASTING METHODS FOR USE BY MILITARY CLUB MANAGERS

AN INDUSTRY PROJECT

Presented to the Faculty of the Hotel School of Florida International University for the degree of Masters of Science by Alfred J. Bender III Marci 1981

In Partial Fulfillment of the Requirements for the Masters of Science Degree 
To Professors:

This project, having been approved in respect to form and mechanical execution, is referred to you for judgment upon its substantial merit.

Bean Gerald W. Lattin

School of Hospitality Management

This project of Alfred J. Bender III is approved.

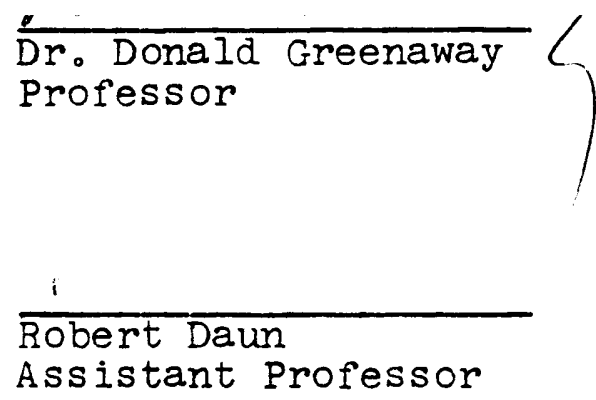

Date of Examination 


\section{BIOGRA PHICAL SKETCH}

Alfred $\mathrm{J}$. Bender III was borm in Alexandria, Louisiana, on July 10, 1944. After graduating from H.V. Cooper High School, Vicksburg, Mississippi, in 1963, he attended Florida Military College in Deland, Florida, for his first two years of college. In 1965 he transferred to the University of South Florida in Tampa, Florida, where he received a B.S. degree in Political Science and Philosophy in 1967. During his school years he held an assortment of food and beverage positions in hotels, motels, restaurants and lounges.

Upon graduation from the University of South Florida, Alfred Bender entered the U.S. Army and received his commission in June of 1968. His entire career has been spent in clubs or club related jobs. Among the more notable positions held are Course Director of the Armys' Club Management Course and Team Chief and team member of Technical Assistance Teams for the Club Management Directorate, Washington, D.C.

Alfred Bender has published many articles concerming club operations and has given presentations at various seminars and club management training courses to include the U.S. Army Executive Club Management Course, presented by Florida International University.

Before entering Florida International University, Alfred Bender attended the Army's Command and General Staff College at Fort Levenworth, Kansas. 
TABLE OF CONTENTS

Preliminaries

Page

BIOGRAPHICAL SKETCH . . . . . . . . . . . ii

TABLE OF CONTENTS .................. i ii

IIST OF EXHIBITS . . . . . . . . . . . . v v

Chapter

I. THE PROBLEM AND ITS SETTING . . . . . . 1

The Statement of the Problem ........ 2

The Subproblems ............. 2

The Hypotheses ..............

The Delimitations ............. 3

The Definition of Terms .......... 3

The Assumption of the Study ... . . . . 5

The Importance of the study ....... 5

II. THE REVIEW OF RELATED IITERATURE • • • • • . 9

Introduction ............. 10

The Historical Background ........ 12

Classes of Methods and Techniques ..... 16

The Forecasting Process . . . . . . 17

The Sales Forecast . . . : : : : 19

Managerial Considerations :. : . . . 21

Forecasting Methods .......... 24

Forecast Evaluation ............ 27

Summary ... . . . . . . . . 28

III. THE POPULATION OF THE STUDY . . . . . . 30

Army Clubs World Wide . . ....... 31

A rmy Clubs Within the United States : : 31

Sample of Club Branches Studied . . . : 32

IV. ANALYSIS OF THE DATA . . . . . . . 34

Analysis of Seasonal, Trend and Cyclical Characteristics of Army Club Sales . . . 35 
Page

Operational Data . . . . . . . 68 Judgmental Forecast Data ....... 68

V. GRAPHIC PRESENTATION OF WORKSHEETS AND INSTRUCTIONS •. • • • • . . . • 71

Worksheet Development ........ 72 Worksheets and Templates ....... 76 Instructions to Worksheets . . . . . . 84 Forecasting Packet Contents . . . . . 95

VI. SUMMARY AND RECOMMENDATIONS . . . . . 97

Summary •. . . . . . . . . 97 Recommendations . . . . . . . . 98 BIBLIOGRA PHY . . . . . . . . . 100 


\section{LIST OF EXHIBITS}

Exhibits

Page

1. Major Command Quarterly Seasonal Indices ... 42

2. Quarterly Seasonal Indices Officers Branches by MACOM . . . . . . . . . . . . . . .

3. Quarterly Seasonal Indices NCO/ENL Branches by MACOM

44

4. Summary of Sample Branch Quarterly Indices, Officers

5. Summary of Sample Branch Quarterly Indices, NCO/ENL ................ 46

6. Correlations Analysis, Officer Branches Major Command Indices

7. Correlation Analysis Mean Indices of Club Branches

8. Summary of Monthly Seasonal Indices . . . . 49

9. Deduced MACOM Monthly Seasonal Indices .... 51

10. Seasonal Indices by MACOM Officer's Branches . . 52

11. Seasonal Indices by MACOM NCO/ENL Branches . . 53

12. Seasonal Indices by DARCOM Officers and NCO/ENL Branches ................ 54

13. Seasonal Indices by TBADOC Officers and NCO/ENL Branches . . . . . . . . . . . . . .

14. Seasonal Indices by FORSCOM Officers and NCO/ENL Branches

15. Summary of Trend Comparison and Correlation of Results ............. . . . . . 
Exhibits

16. Summary of Major Command Cyclical Factors . . 66

17. Summary of Economic Cyclical Indicators and

Summary of Correlation Coefficients for: Cyclical Indicators (vs) Army Club Sales Cyclical

Factors. 
I. THE PROBLEM AND ITS SETTING 
THE PROBLEM AND ITS SETTING

The Statement of the Problem

The purpose of this study is to adapt and combine the following methods of sales forecasting: Classical Time-Series Decomposition, Operationally Based Data and Judgmental Forecasting for use by military club managers.

The Subproblems

The first subproblem consists of testing the seasonal, trend and cyclical components of the Classical Time-Series Decomposition Method of sales forecasting as they relate to military club sales.

The second subproblem consists of the simplification and formatting of the mechanics of the Classical Time-Series Decomposition Method through the use of graphic display techniques. The third subproblem consists of the idertification and formatting of pertinent operational data useful in formulating a sales forecast.

The fourth subproblem consists of the identification and formatting of the judgmental considerations that effect the formulation of a sales forecast. 
The Hypotheses

The first hypotheses is that the sales history of a military club reflects the seasonal, trend and cyclical characteristics which are comoonents of the Classical Time-Series Decomposition Method.

The second hypotheses is that the Classical Time-Series Jecomposition, Operationally Based Data and the Judgmental Methods of forecasting can be simplified and formatted through the use of graphic display techniques into a series of worksheets.

The Delimitations

The study is limited to military clubs.

The study is limited to clubs operating in the

Continental United States.

The study is limited to the short and medium term

forecasting horizon.

The Definition of Terms

Forecasting. Predicting with reasonable probability what will happen within a given set of circumstances within a specified time frame.

Short Term Time Horizon. One to three months. Medium Term Time Horizon. Four to eighteen months. 
Time-Series. Method of data measurement in which time is the independent variable.

Military Club. A non-appropriated fund instrumentality of the U.S. Government with the principle purpose of providing focd, beverage and entertainment activities at a profit to a closed membership. The individual club is the basic unit of pinancial reporting.

Officer, Noncommissioned Officer and Enlisted Club Branches. An organizational element under which individual clubs of each category fall. It provides centralized management for each category of clubs. It also is a unit for financial reporting purposes, providing a consolidation of the individual clubs within each category.

Annex. The individual operating club.

Community club. A club open to a mixture of ranks, witr a central kitchen and common or separate dining rooms and cocktail lounges.

Installation Club System. An organizational element providing centralized executive management for the club brarches as defined above. This furction is headed by the Installation Club Manager (ICM)。 
Major Army Command (MACOM). This is a major organizational element within the U.S. Army. It is comprised of various installations containing club systems. Club sales figures are totaled by MACOM.

The Assumotions of the Study.

The first assumption is that no formalized or objectively based method of forecasting sales for military clubs currently exists.

The second assumption is that automatic data processing is not available to the operational club managers. The third assumption is that the management force does not possess an extensive statistical or mathematical background. The fourth assumption is that an accurate and meaningful sales forecast is the primary element in the budgetary process. The fifth assumption is that the proposed system will have an accumulative capability operating from the lowest level. of sales/profit center management upwards to the executive level for the establishment of system wide forecasts.

The Importance of the Study

Today, with increasing economic pressures being felt by the military club food and beverage operations, there is a 
critical need for sales forecasting. A reasonably accurate forecast is fundamental to effective profit planning. Without an objective estimate of sales for the coming period, the budgetary process cannot be meaningful. Probably the most significant aspect of this study is that currently no system of forecasting exists. Furthermore, the implications of poorly formed forecasts are not understood by operators at all levels. The common practice is to simply add ten percent to last years sales and budget accordingly.

One of the major weaknesses of the management system is that great emphasis is placed on operational budgets, their tinely submission and the achievement of buageted goals. However, with the exception of a few very general training dccuments, little or nothing has been provided the operator in terms of how to accomplish this very critical first step in the planning and budgeting process.

This system will provide management with a mocierately sophisticated forecasting methodology in a simplified format. Through this vehicle, the manager that does not possess an extensive mathematical or statistical background can prepere a forecast based on a proven technique.

A major benefit that will be derived from such a system 
would be the ability of the executive manager to consolidate operational forecasts, thus producing a system wide forecast. In fact, this could be expanded to regional, or righer, organizational levels.

An additional consideration is that it is quite possible that this system would have commercial applications. The primary users would be small to medium size, privately owned restaurants or multiple operations seeking a degree of centralized budget control and profit planning.

The system is composed of several large worksheets. These are graphically designed in such a way that completion of each worksheet will be accomplished through a step by step process. The first sheet contains the basic sales data necessary for calculation of the time series portion of the forecast. The second worksheet provides for the recording of the results of worksheet $I$ that is a seasonal index and a representative curve. It also provides the format for the calculation and fitting of the least squares trend line. Worksheets 3 and 4 format food and beverage cperational data. The fifth worksheet organizes the judgmental considerations through a series of questions. The sixth and final worksheet formats the formation of the final forecast and forecast 
evaluation.

Although the system is designed as a wrole unit, the segments may be used alone, depending on the amount and detail of data available at an individual club. Additionally, the system will provide a basis for more advanced methods if automatic data processing becomes available. 
II. THE REVIEW OF THE REIATED IITERATURE 


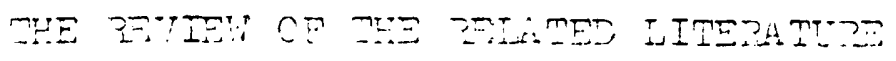

Introdustion

The to. Army orerates 6ir clubs worid wio. Tie cluh Bustem is consistently ranked in the ton fistu ne tre tretitutions lon. Yaritually, arnoximately ono thinr nf al. aluise aro uncropitable. To bexin to understand the roed fon the proposed study, one noeds exposure to srme of the beald cramaztenistics that set the nilitam alub arant from commencial oremitions. Mo fully fathom the torkinge of the clubs, cre must he araro of two funzamental, but cpossing, foroos that rak oonEtantly on the day to day operaticns of the club. ane first force at work is that the militam clubs orenete ntth in the roremmental bureaucracy. This fact accounts fon, what sone nefer to, as an over controlled situation. In fect, orenetisns at militarir clubs are zovemed by maseive amante of rolioy sar romilatichs. These also imract on ctren aspects of clik operations which will be discussed later. when this youscteristic is viewed areinst the rackeround of the iasia enterroise rature of club operetions, it is easy to soe the gruosir. fompes at work. By its raturo, the food and roverazo bustrese is hiohly comnetitive. consoquently, renarement mult be abie to

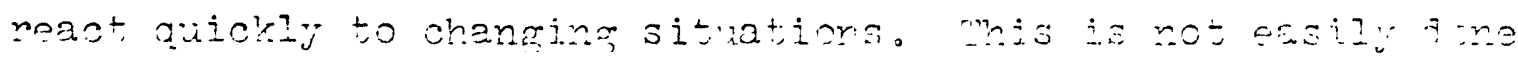


when a manager has to pull the weight of the bureaucracy to react to an opportunity.

Now on to some specifics; there are five basic aspects that contribute a need for a sales forecasting system. They are: The Market, Operating Cost, The Pricing Structure, The Profit Motive and the Budgetary Process. Each will be briefly discussed in turn.

The Market. The military club market is very discreet, easily identified and presumably easy to reach. Regardless of these factors the club has to compete with the commercial sector. This is true primarily because the military family is more mobile and affluent today than ever before.

operating Costs. Generally speaking, administration overhead and administration operating costs for military clubs are twice that of a commercial restaurant. This is primarily due to the massive amount of policies, procedures and regulations within which clubs must operate. Principal among these are the personnel policies, administration of the accounting function and influences of non-operationally oriented agencies. The Pricing Structure. Essentially, the pricing structure is lower than similar competing operations. This is of $\mathrm{f}$ set, in part, by dues income. However, operating margins are 
comparably lower. Consequently, the ability to meet a significant contribution margin to cover fixed costs (those abnormally high administrative costs) is often times severely restricted. Profit Motive. Probably the single most important aspect that sets the military club apart is the lack of profit motive. Management personnel have no vested interest. Directly, or indirectly, the majority are paid through appropriated funds. Profit needs, by policy, are only to be sufficient to fund the capital improvement program.

Budgetary Process. The emphasis of the budgetary process is not operational, it is instead focused toward fulfilling a requirement from Washington. The techniques and approaches to this process are not oriented toward an operating budget that is a tool in the hands of the manager.

When these characteristics are considered, it is easy to see that the line between a profitable and unprofitable operation is very thin. Therefore, as a fundamental element in the profit planning process, a forecasting system that can be used by the average operator is seen as a valuable asset to the system as a whole.

Historical Background

The crystal ball is probably the oldest form of 
forecasting used to reduce the uncertainty of future events, and, without a doubt, it probably sees some use today. Because it never really proved to have a degree of reliability, the forecaster soon sought methods that provided at least some measure of accuracy. Within the last twenty-five to thirty years the body of knowledge, represented by the term forecasting, has grown at an ever accelerating rate. This is primarily due to the staggering advances in the field of computer science.

In their book, Forecasting Methods For Management, Steven C. Wheelwright and Spyros Makridakis make a significant point concerming growth and importance of forecasting today.

"The past decade has seen a number of developments in the area of forecasting methods that can be used in business. These advances in theory and practice have been the result largely of the increasing business environment. Companies of all sizes now find it essential to make forecasts for a number of uncertain quantities that affect their decisions and their performance."I

This point establishes the operational context for both civilian and military food and beverage operations. The military clubs have to compete in the same general economic

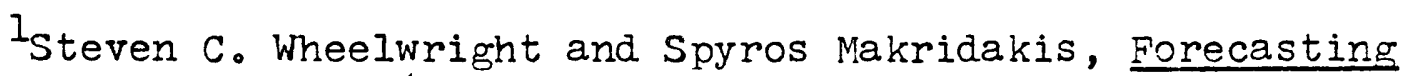
Methods For Management (New York: New York, John Wiley \& Sons, 1973), p.VII. 
and competitive environment as their civilian counterparts. The civilian segment of the market has moved to develop and utilize forecasting models while the military segment has done little or nothing in this area.

Wheelwright goes on to point out that...

"A key aspect of an decisionmaking situation is being able to predict the circumstances that surround that decision and that situation. Such predictions, generally handled under the title of forecasting, have been identified as a key subpart of the decision-making process." 2

Classes of Methods and Techniques

Forecasting methods can generally be divided into three broad categories, they are: . . "the näive method, the barometric method, and the analytical method." 3

The general premise of the näive method is that, within a given set of circumstances, the future will mirror the past. This category of techniques can range from a simple coin toss to a complex time-series.

2 Ibid., p. 1。

${ }^{3}$ Carl Heyel, ed. The Encyclovedia of Management, 2nd Ed., (New York: New York, Van Nostrand Reinhold Co., 1973), p. 75. 
"The barometric method implies that past historical patterms tend to repeat themselves in the future, and that it embraces the idea that the future can be predicted from certain happenings of the present. Thus, past statistical behavior that seems to be associated regularly with fluctuations in particular series or general business conditions is discovered and used as a basis for forecasting." 4

"The analytical method entails detailed analyses of causative forces operating currently on the variable to be predicted. Relationships of cause and effect disclosed by analyzing current data are used to judge the future course of the causative forces and their effects on the future behavior of the variable to be predicted." 5

These three categories can be further narrowed to two general classifications they are: quantitative and qualitative techniques. The quantitative techniques as characterized by Wheelwright are...

"Those techniques that start with a series of past data values and then, following a certain set of rules, develop a prediction of
future values. . b

${ }^{4}$ Ibid., p. 76.

5 Ibid., p. 76 .

${ }^{6}$ Wheelwright and Spyros, op。 cit., p. 4. 
This is then contrasted to the qualitative techniques which are based on managerial judgment and subjective analysis. The absence of historical data or incomplete data usually necessitates the use of this category of techniques.

It is easy to see that these two approaches to classification are interrelated. For example, a method based on the näive premise could be either qualitative or quantitative, or both. As a matter of fact, upon close examination it becomes evident that different approaches, applied within the first three categories, can easily fall within either or both of the quantitative or qualitative classifications.

Generally speaking, a combination of quantitative and qualitative techniques is the optimum for developing a forecasting methodology for a particular firm. In the final analysis, the primary objective of business forecasting is the development of a sales forecast. In their book, "The Management of Sales Forecasting, Eby and O'Neill of Villanova University provide the following definition:

"A sales forecast is defined as the sales volume a firm expects to realize during a designated future time period."?

7 Frank H. Eby, Jr. and William J. O'Neill, The Management of Sales Forecasting (Lexington, Massachusetts: Lexington Books, 1977), p. I. 
The Forecasting Process

Jerome McCarthy in his widely used text on marketing establishes the sales forecast formulation as a three stage process :

"1. Develop an economic forecast for the whole economy and use this to ...

2. Develop an industry sales forecast, which in turn is used to...

3. Develop a specific company or product forecast." 8

The development of the economic forecast as outlined by Doctors Murdick and Schaefer is based upon broad economic indicators such as ...

...."Gross National Product, money supply, debt, production and working hours, employment and unemployment, disposable income, distribution of wealth and income, prices at all levels of production and distribution, taxes and international trade and financial conditions."

Also included in this forecast are social, political and legal considerations that will have an impact on the firm and its products. The next step focuses on how the particular industry

8. Jerome McCarthy, Basic Marketing a Managerial Approach, 4th ed., (Homewood, Illinois: Richard D. Irwin, Inc. 1971), p. 117 .

${ }^{9}$ Robert G. Murdick and Arthur E. Schaefer, Sales Forecasting for Lower Cost and Higher Profits (Englewood Cliffs, New Jersey: Prentice-Hall Inc., 1967), p. 3. 
will fare in the projected economic climate. This is usually approached through an analys is of several factors identified in the economic forecast that are closely related to the industry, such as the price of gasoline and the automobile industry .

The final forecast is that of the firm. At this level the full array of forecasting techniques and methods may be employed. The formation of the individual firms forecast is obviously the most critical aspect of the forecasting process. This is primarily the level at which the proposed study will concentrate. When this methodology of macro to micro forecasting is related to the military club several points required comment. The market context of the military club is such that the usefulness of the industry and economic forecast is questionable. The ability of the military club to expand its market is quite limited and very definitive, consequently industry growth projections, i.e., (real growth), are of little significance. Along the same vein, the general economic forecast has little direct impact upon the formation of the forecast at the military club level. One of the results of this study will be a determination of the relationship of club performance to the general business cycle of the economy. At this point, the basic supposition is that because of the 
nature of the military club market, there is not a significant relationship relative to forecast formation. The Sales Forecast

The importance of the sales forecast cannot be overemphasized. Murdick and Schaefer establish and echo a consensus opinion.

"There are few, if any, functions

of business which are more fundamental

and far-reaching in their effect or the health of the enterprise than the forecasting or prediction of future sales." 10

Sales forecasting is the primary element in the development of any enterprise plan. This point is stressed by Ya-Iun Chou of St. Johns University. . "Plans for the future cannot be made without forecasting events and their relationships." 11 The most significant plan of any business is its profit plan. Once again Murdick and Schaefer provide the context for the importance of the forecast.

"Since forecasts must precede the development of final plans, forecasts of all company activities based upon sales forecasts represent the starting point for profit planning."12

${ }^{10}$ Ibid., p. 6.

$11_{\text {Heyel, }}$ opo cit., p. 75

12 Murdick and Schaefer, op. cit., p. 8 
Profit planning is nothing more than sound budgeting. The budgetary process, in varying degrees of complexity, is common to all businesses. The importance of the sales forecast, in relationship to the budget, is unanimously proclaimed by the recognized authorities in the field of management. Koontz and O'Donnell reinforce this in their pre-eminent text of management science. "One of the major planning premises in the typical business enterprise is the sales forecast."13

This point is further emphasized by authorities witrin the food and beverage industry. Bolhuis and Wolff, in conjunction with the editors of The National Institution For the Food Service Industry (NIFI) publication, state that . .

is the first step in the budget-
making process. It is also the
most important step since all
experse is related to sales vol-
ume."14

This thinking is echoed by Fay, Rhoads and Rosenblatt in their book Managerial Accounting For the Hospitality Service Industries, which is typical of such publications on the subject.

13 Harold Koontz and Cyril O'Donnell, Principles of Management: An Analysis of Managerial Functions, 4th edo, (New York: New York, McGraw-Hill Book Company, 1972), p. 163.

$14 \mathrm{John}$ L. Bolhuis and Roger K. Wolff, The Financial Ingredient in Foodservice Management (Lexington, Massachusetts: D. C. Heath and Company, 1976), p. III. 
The preceding comments only serve to underline the importance of this study. Annually, the agency that has the technical responsibility for Army Club Management issues budget guidance and preparation instructions. However, there is no procedure or guidance directed toward the formation of the vitally important sales forecast. Managerial Considerations

The next segment of this review will consider those factors that management must weigh when selecting a method of sales forecasting.

The first factor, and probably the most far reaching in terms of the overall performance of a forecasting system, is the time horizon. It is essentially the time period in the future for which the forecast is formulated.

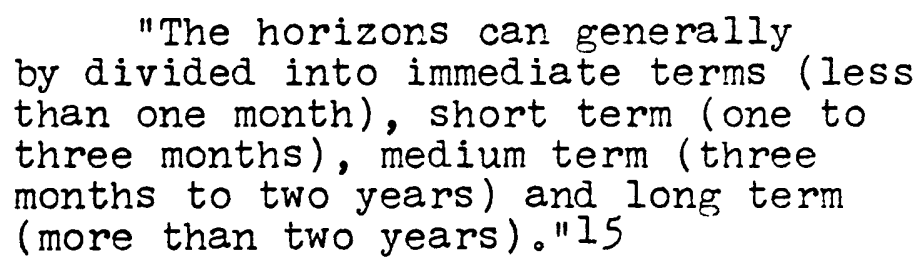

The next factor to be considered is the level of detail of the forecast. This aspect is directly related to how the decision making process is structured and subdivided. The forecast may be structured for a complete product line, a single product or the sales of an entire company.

15Wheelwright and spyros, op。 cito, po6. 
The accuracy of the forecast metrod obviously is a major factor in selection. Authorities warm management not to select forecasting methods based on the so called "Rules of Thumb" of plus or minus 3, 5 or 10 percent from actual performance. Reichard, in his work entitled practical Techniques of Sales Forecasting states...

"One thing is certain: No firm should be satisfied unless its salesforecasting program yields results that are significantly better than would have been attained from informal sales-department estimates or some standard forecast issued by the industry trade association or the govermment." 16

The level of accuracy is a function of many factors such as the length of the forecast, the level of detail, the variability of data, and the state of the art of the chosen method. In the final analysis the accuracy is judged by one factor, as pointed out by Sartorius and Mohn in their work Sales Forecasting Models: A Diagnostic Aporoach.

"In forecasting there is only one ultimate measure of accuracy: How close are the sales forecasts to the actual sales reported later?"1?

${ }^{16}$ Robert S. Reichard, Practical Techniques of Sales Fore-

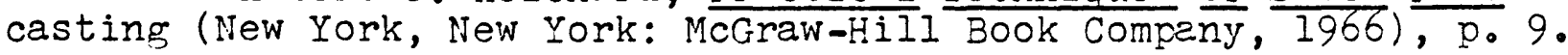

17 Lester C. Sartorius and N. Carroll Mohn, Sales Forecasting Models: A Diagnostic Approach (Atlanta, Ceorgia: Publishing Service Divo, College of Business Administration, Georgia State University, 1976), p. 3. 
Cost of the system employed is also a critical consideration. Wheelwright and Makridakis provide a precise summary of the factors to be considered relative to cost.

"Generally four elements of cost are involved in the application of a forecasting procedure: development, storage, actual operation and opportunity in terms of other techniques that might have been applied. The variation in costs obviously has an impact on the attractiveness of different methods for different situations." 18

Obviously there are many other factors to be considered in selecting a method of forecasting. These are only the most significant in terms of overall results. However, there is one additional factor that wheelwright brings up that probably has the most direct impact upon this study. He points out that when scientific methods are applied to management, the decision maker will only use those methods that are understood. He goes on to state...

"This is particularly true in the area of forecasting, since the manager is held responsible for his decisions, and he is certainly not going to base them on forecasts that he does not understand or in which he has no confidence." 19

$18_{\text {Wheelwright and Spyros, op. cit. }}$ p.90 ${ }^{19}{ }_{\text {Ibid., p. } 9 .}$ 
This waming is central to this project.

It becomes evident that when these factors are considered relative to the military club, they take on a somewhat different light. The time-horizon has to be viewed in the short and medium term context. The principal reason for this limitation is that the profit motive and objective for the club is not quite as critical as in the civilian sector. Sufficient profit to support a capital improvement program for the property is the fundamental objective. Consequently, the forecasting orientation has to be operational. As to the accuracy of the forecasts, the same considerations apply to both sectors. The aspect of cost focuses attention on one of the major benefits that will result from this study. The only cost of any significance, as it relates to the forecasting function, will be managerial time. Finally, the guiding principle for this project revolves around the idea that the user must understard and accept the methodology in order to have confidence in the system. If the major objectives of this project are accomplished, this consideration will be essentially satisfied. Forecasting Methods

There are approximately eighteen to twenty-five accepted basic techniques used in sales forecasting. A summary of these 
and other methods can be found in any authoritative source on the subject. Consequently, only the more significant individual methods will be mentioned.

Qualitative Methods

This category includes such methods as Delphi, Market Research, Panel Consensus, Visionary Forecast, and Historical Analogy. Generally speaking, these methods are used for long range forecasts. The common element of these methods is that they involve judgment either by group or individual. They differ essentially in how the subjective process is structured. Although these methods normally deal with long range time horizon, certain structural elements will have application in the proposed study. There are always elements that must be included in a forecast that cannot be quantified, consequently managerial judgment is necessary. It is the intent of the study to format, from a procedural point of view, relevant aspects of the juagmental methods.

Quantitative Methods

This category can be further subdivided into two subgroups. They are, Time-Series Analysis and Projection and Causal Methods.

The time-series category is where the emphasis of this 
study will focus. Methods included in this grouping are: Moving Averages, Exponential Smoothing, Box-Jenkins Exponential Smoothing, Classical Decomposition and Trend Projections. These methods are well suited for the immediate and short range time horizon. Another characteristic that makes these methods relevant to this study is their relative simplicity and accuracy for the time period considered. The components that will be drawn from these methods are seascnal, trend and cyclical indicators of the club business.

The causal methods are somewhat more complex, and, for the most part, require automatic data processing capability。 However, this does not preclude the adaptation of various elements for use in the project. The most notable among these methods are: Regression Model, Econometric Models, Intention to buy and anticipations surveys, Input-output models, Diffusion index, Leading indicator, and Life-cycle analysis.

Several very useful matrices have been developed that facilitate the choice of which system is best suited for a particular need. The most noteworthy of these are found in the Sartorius and Mohn publication and the Wheelwright and Spyros book, both of which have already been noted. There is one class of forecast that is not found in the 
area of statistical techniques. This class is referred to as operational data as it relates specifically to the food and beverage industry. This data is generally treated under the topic of budgeting. However, it has already been established that the budget is dependent upon the forecast. The data referred to is the base data required to calculate a forecast of sales for food and beverage operations. This type of data includes the followin: number of seats, seat tumover rates, average check, days of operation, hours of operation and annual average sales per seat. 20 It is the combination of this data with that derived statistically and judgmentally that will produce the final forecast. Forecast Evaluation

The final aspect of a forecasting system is the evaluation phase. Here the thrust is directed to the establishment of tests that track the relative performance of the system. "Some of the more common yardsticks are those that:

1. Measure the absolute difference between actual and projected sales.

2. Measure the percentage difference between actual and projected sales.

3. Evaluate differences in the direction and timing of any changes in basic sales trends.

${ }^{20}$ Michael M. Coltman, Hospitality Management Accounting, (Boston, Massachusetts: CBI Publishing Company, Inc. 1978), pp. 243-244. 
4. Compare projected results with those obtainable from more naive models.

5. Compare results in the light of expected statistical variation." 21

All of these methods are suitable to the proposed study and will be incorporated at different degrees of complexity. The net result of evaluation is the refinement of the forecasting process which will develop answers to the following questions:

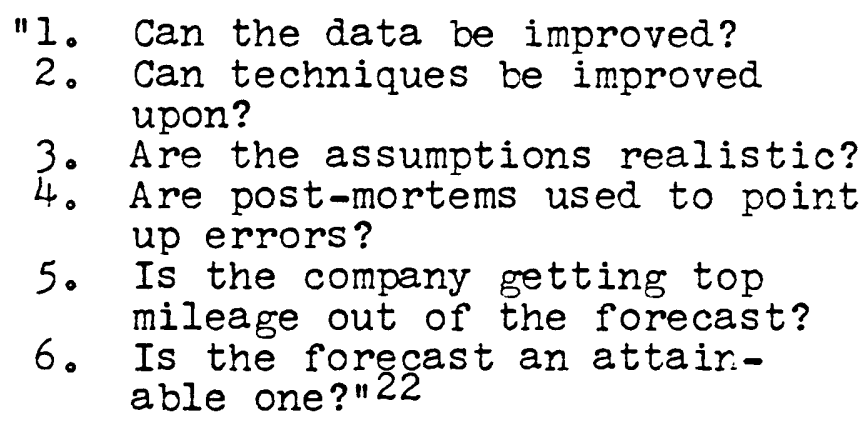

The actual refinement of the system will be the responsibility of the user. This will be dependent upon such variables as relative education and interest in the system.

Summary

The significance of the preceding is that the methods and techniques are available. They are well developed and are in use throughout the business community. The importance of
${ }^{21}$ Reichard, opo cit., p. 235.
22 Ibid., p. 253 and 204. 
forecasting is clear. The task is the adaptation and modification methods in order to satisfy the assumptions of the study and the criteria for a valid sales forecast.

The methodology employed in this study focuses on testing the hypothesis that a time series based technique is suitable. Determinations of the relative strength and importance of the seasonal, trend and cyclical factors is central. Based upon the results, the final procedure will be formatted with complete step-by-step instruction. The second portion is directed toward the identification and formatting of the necessary operational data. This is followed by the judgmental aspects and finally forecast formation and evaluation. The true significance is that, for the first time, a manager of the military club will have a device for the foundation of an objective sales forecast. 
III. THE POPULATION OF THE STUDY 
Army Clubs World Wide

The United States Army operates 142 installation club systems world wide. This total is composed of 110 officers branches operating 194 annexes, and $108 \mathrm{NCO} /$ enlisted branches with 401 annexes. In addition, there are 35 community branches with 52 annexes. There are also 71 package beverage branches with 120 operating stores.

Army Clubs Within the United States

Within the United States, the Army operates 92 installation club systems containing 75 officers branches with 111 annexes and 68 NCO/enlisted branches with 162 annexes. For the purpose of this study, only officers and NCO/enlisted branches were considered. Package beverage branches and community branches were excluded. When community and package heverage branches are excluded from the world wide totals, the U.S. branches represent 66 percent of the total, with Europe and the Far East representing 29 and 5 percent respectively. In order to establish a basis for the sample, each of these major groupings were viewed in terms of total revenue contribution. The U.S. branches account for approximately 56 percent of total revenue with Europe at 33 percent and the Far East at 11 percent. The next iteration distributes 
the officers and NCO/enlisted branches as a percentage of the world wide total.

\begin{tabular}{lclll}
\multicolumn{2}{l}{ Officers } & Branches & & \multicolumn{2}{l}{ NCO/Enlisted Branches } \\
U.S. & $70 \%$ & & U.S. & $47 \%$ \\
Europe & $23 \%$ & & Europe & $39 \%$ \\
Far East & $7 \%$ & & Far East & $14 \%$
\end{tabular}

The sample drawn consists of club branches from three U.S. major commands - they are Forces Command, the Training and Doctrine Command and the Material Development and Readiness Command. These three commands represent 82 percent of total U.S. revenue. This percentage is croken down as follows:

$$
\begin{array}{lr}
\text { FORSCON } & 41 \% \\
\text { TRADOC } & 32 \% \\
\text { DARCOM } & 9 \%
\end{array}
$$

When this distribution is viewed from the officers and NCO/enlisted branch standpoint, the officers branches of these three commands represent 75 percent of total officers branch revenue for the U.S., while the NCC/enlisted branches account for 87 percent of total U.S. NCC/enlisted branch revenue.

Samnle of Club Branches Studied

The individual club branches selected for study are 
as follows:

FORSCOM

Ft. Bragg, N.C.

Ft. Devens, Mass.

Ft. Hood, Tex.

Ft. Lewis, Wash.

Ft. Riley, Ks.

- 22\% of Total

officer and

$\mathrm{NCO} / \mathrm{enI}$.

Branches

- 33\% of MACOM

Total Revenue

\section{TRADOC}

Ft. Belvoir, Va.

Ft. Gordon, Ga.

Ft. Harrison, Ind.

Ft. McClellan, Ala.

Ft. Leonard Wood, Mo.

- 23\% of Total

officer and

$\mathrm{NCO} / \mathrm{enl}$.

Branches

- 23\% of MACOM Total Revenue
DARCCM!

Aberdeen Proving Gr., Md. Dugway Proving Gr., Ut. LeFerkenny Army Depot, $\mathrm{Pa}$. Missle Mat. Readiness, Ala. Ft. Nonmouth, N.J.

- 30\% of Total cfficer and NCO/enl. Branches

- 49\% of MACCM Total Revenue

The primary intent of the sample selection was to insure geograchical representation and representation in terms of volume.

Although this sample could not be considered a random sample or a scientifically established sample, it is believed to be representative of the U.S. club branches.

The above percentage figures are based on FY 1979 totals. 
IV. ANALYSIS OF THE DATA 
Analysis of Seasonal, Trend and Cyclical Characteristics of Army club Sales.

An analysis of the Seasonal, Trend and Cyclical components of the Classical Deposition Method of Time-Series was undertaken with two primary objectives in mind. The first was to determine the relative strength of these factors within the context of Army Club Sales. The second was to eliminate for the sake of simplification, those factors of little or significant impact on Forecast formulation.

\section{Seasonal Factor}

The first component subjected to evaluation was the seasonal factor. This analysis focuses on the development and testing of seasonal indices with the intention of identifying seasonal characteristics that are representative of the commands and classes of club branches. The base data for these calculations are forty-eight months of sales history. The indices are calculated based on the ratio of actual sales to a 12 month moving average, which express sales as a percentage of the current annual average which is represented by 1.00 or 100\%, for sampled officer and NCO/ENL Club Branches. Monthly sales data for the Major Commands selected was not available. 
However, the Major Command totals were available on a quarterly basis for the same period.

The first step in the evaluation was the calculation of a quarterly index for each Major Command. These calculations were based on the ratio of actual sales to a four point moving average. The results are summarized in Exhibit 1 . In order to determine the extent of individuality of each curve, the means of each were tested against each other within the same category. The difference was tested using the .01 level of significance. The results indicated no significant statistical difference. The next step was to test the means of each command by category (i.e.) officers vs NCO/ENL. Once again there was no significant statistical difference. Finally, a test of difference between the means of the quarters by category was conducted. The results confirmed a significant difference in the second quarter. The implications of this resultant are quite interesting. Visual inspection identifies the second quarter of the fiscal year as the annual low point for all commands in the officer category. Contrary to this is the second quarter results for the NCO/ENI category, which is only slightly above the mean. It has been a commonly held opinion that the second quarter was the poorest of the year 
for all categories. Based upon these findings, it appears as though the NCO/ENL category is not affected to same extent as the officer category by this post-holiday period and the midwinter slump. These results are further depicted graphically in Exhibits $2 \& 3$.

Continuing with the analysis of the quarterly figures, indices where calculated for each club branch contained in the sample with the following exceptions: Ft. Riley, Kansas, officers branch, which underwent closure and subsequent reopening as a new club during this period and the Dugway Proving Ground Officer and NCO/ENL Clubs which were combined during this period. The results are summarized in Exhibits 4 \& 5 .

With few exceptions, it should be noted that these curves correspond to the Major Command indices. However, it should also be noted that the DARCOM officer branches have the greatest degree of variability.

To what extent do these individual indices represent the total Major Command indices was the next major question to be addressed. In order to test this aspect each Major Command index was treated as a population mean. An .01 level of significance was established for the test of significant difference. No statistically significant difference was noted between the individual club branch indices and those of their major command. 
To explore further the relationships among the Major Commands and how they might differ, the coefficient of correlation and determination was calculated for the most significant combinations. First the indices were correlated by MACOM and by category. The results indicate a high degree of relationship between officer branches of all three commands. Conversly, a relatively low degree of relationship was revealed between the NCO/ENL branches of the three commands. The next step was to see if there was any significant relationship between the officers and NCO/ENL branches within the same MACOM. The result was as expected, there is no meaningful relationship between officer and NCO/ENL seascnal characteristics. Put another way, the character of the seasonal buying habits expressed by club branch sales of officer and NCO/ENL categories are mutually exclusive. The results of the above analysis are presented in Exhibits 6 and 7 . The calculation of a monthly seasonal index for each individual branch sampled was the next step in the analysis. These indices are provided in Exhibit 8. Following the logic that the mean of the individual quarterly indices do not differ significantly from the MACOM indices, it seems reasonable to assume that the mean of the monthly indices would be repre- 
sentative of the MACOM. Therefore, a montriy index for each MACOM could be deduced. These indices are presented in Exhibit 9. When these indices are correlated the same general relationships hold true as previously stated with reference to the officer and NCO/ENL seasonal curves. Exhibits 10 and 11 depict the annual curves by category, while Exhibits 12 through 14 portray officer and NCC/ENL curves by Major Command. These graphic presentations only reinforce the relationships established through the statistical analysis.

\section{CONCLUSIONS}

There can be little doubt of the significance and importance of the seasonal characteristic of military club sales. Specific considerations and implications of the analysis will now be addressed.

The first, and most obvious, conclusion is that little or no relationship can be drawn between officer and $\mathrm{NCO} / E N L$ seasonal curves. Moreover, the NCO/ENI sales history and performance is not subject to the post holiday down turn that is so strong in evidence for officer branches. The reason for this behavior is beyond the scope of this project. However, it is significant and should be an object of further research. Secondly, with only a few minor exceptions, the indices 
for the individual branches are clustered closely about the ir mean with only a small amount of variability. The most notable exception to this is the DARCOM officers branches, which have the greatest degree of variability. This would logically lead to the conclusion that the individual branches within this command group are less alike, seasonally speaking, than the other two groups.

Third, it could be concluded that, as a group, officer branches are a more homogeneous group than that of the NCO/ENL branches with respect to their seasonality.

Fourth, there are some very unique aspects of each of the major command curves that warrant discussion. The TRADOC officers curve reveals a sustained drop through the first five months of the fiscal year. Cenerally speaking, this is a significant characteristic unique to TRADOC. Understanding that TRADOC is the training command for the Army, it would be a logical deduction that because the schools normally close in mid-December and major portions of the population depart, that this period will be lower than the other commands. This, coupled with the normal depression of the winter season, explains, in part, this characteristic.

The FORSCOM and DARCOM officer branches experience a 
peak during December. This could be attributed to the fact that these are generally stable communities. The holiday season is a period of increased social activity which has an obvious impact of club sales. However, this peak is followed by the same mid-winter drop experienced by the other commands. All three experience the annual peak during the early summer months and generally tail off as summer ends and the school season returns. The NCO/ENL branches are characterized by a less variable annual curve.

In summation, these seasonal curves are in an obvious state of change. Observant management must be aware of these changes and make an effort to discern the causes for major shifts. It is easy to see the importance of the seasonal index as it is employed in the forecasting function of management. 
EXHIBIT I

MA JOR COMMAND QUARTERLY

SEASONAI INDICES

FY 77-FY 80 BASE
$1^{\text {st }}$
$2^{\text {nd }}$
$3^{\text {rd }}$
$4^{\text {th }}$

Officers Branches

\begin{tabular}{|c|c|c|c|c|c|c|c|}
\hline FORSCOM & & .9567 & .9433 & 1.08 & 1.0167 & $\overline{\mathrm{x}}$ & $=.9992$ \\
\hline TRADOC & & .94 & .91 & 1.11 & 1.05 & $\overline{\mathrm{y}}$ & $=1.0025$ \\
\hline DARCOM & $\begin{array}{l}\vec{x} \\
s\end{array}$ & $\begin{array}{l}.99 \\
.9622 \\
.0255\end{array}$ & $\begin{array}{l}.91 \\
.9204 \\
.0180\end{array}$ & $\frac{1.09}{1.09}$ & $\frac{1.00}{1.02}$ & $\begin{array}{l}\bar{X} \\
s\end{array}$ & $\begin{array}{l}=.9975 \\
=.0737\end{array}$ \\
\hline
\end{tabular}

NCO/ENL Branches

FORSCOM

$\begin{array}{llll}.9833 & 1.01 & 1.01 & 1.00\end{array}$

$\bar{x}=1.0008$

TRADOC

.96

1.0033

1.0250

1.0433

$\mathrm{s}=.0126$

DAPCOM

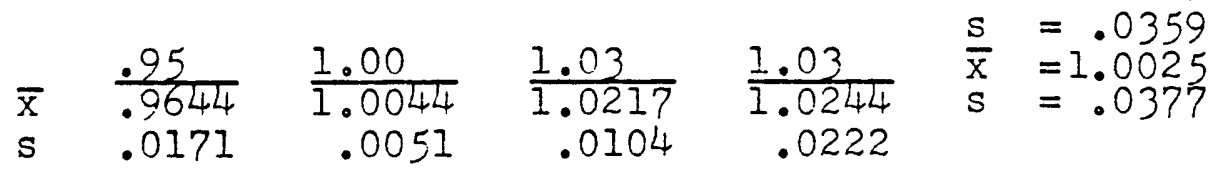




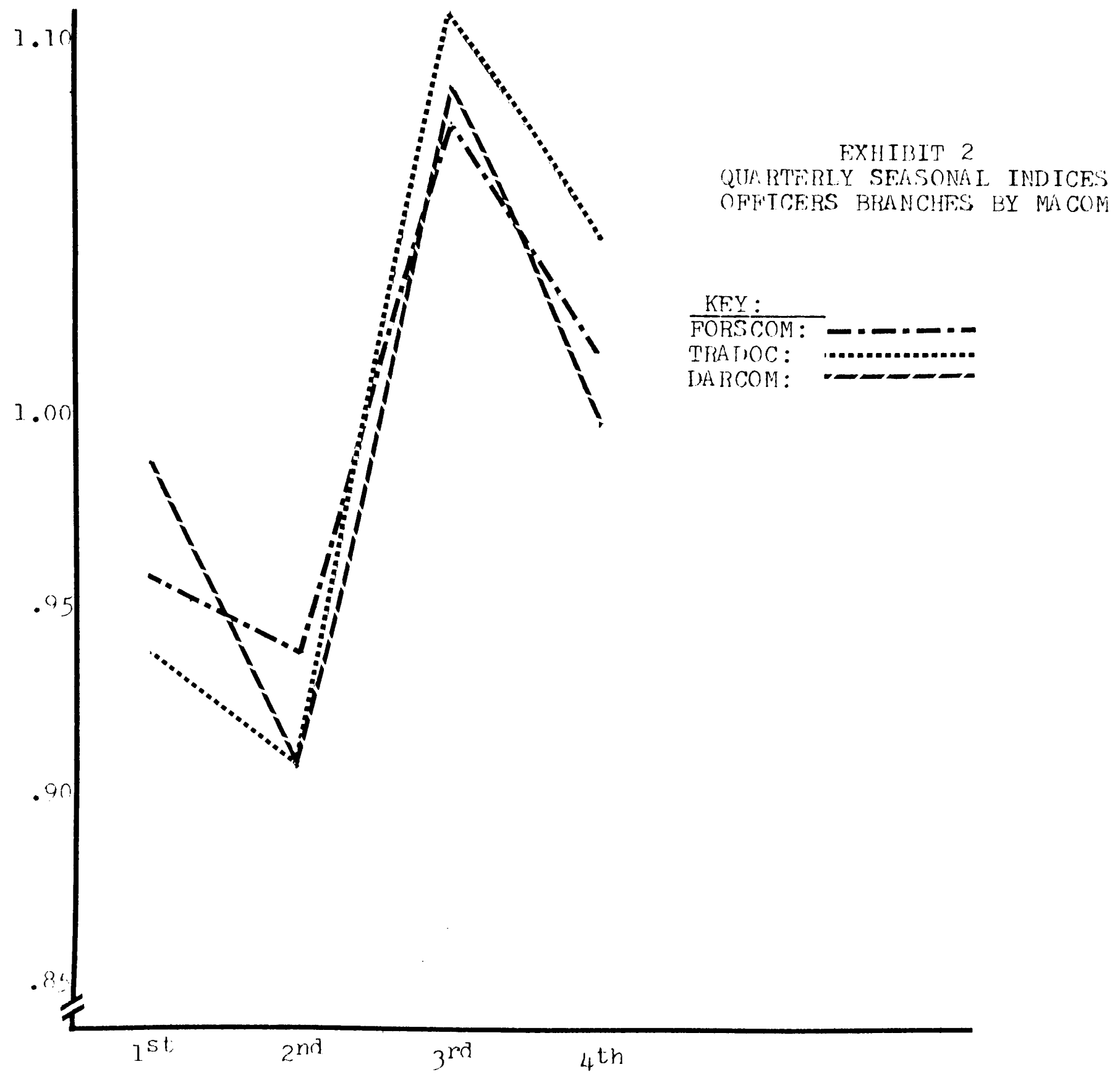




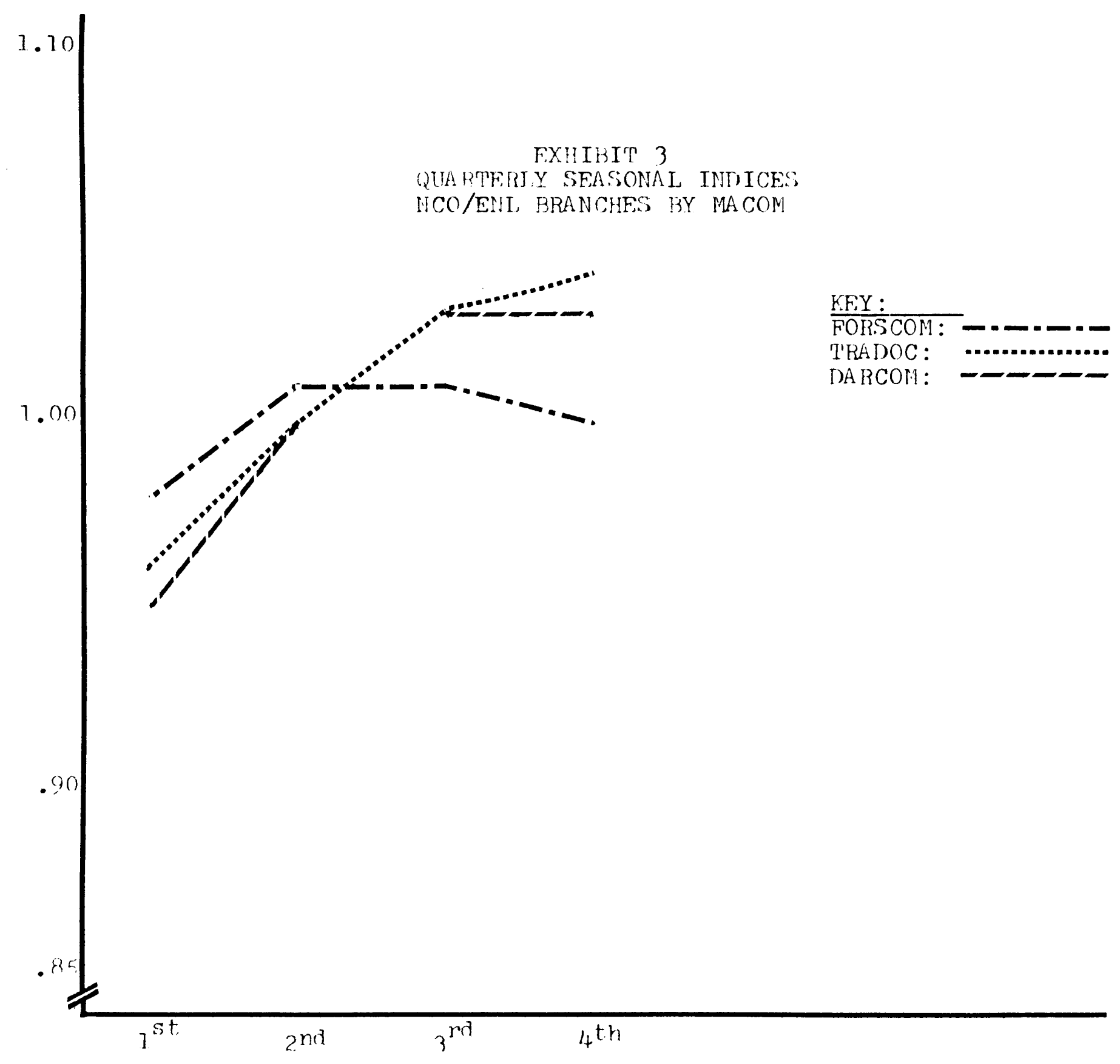


EXHIBIT 4

SUMMARY OF SAMPLE BRANCH QUARTERLY

INDICES FY 77-FY 80 BASE

OFFICERS

Ist $^{\text {nd }} \quad 3^{\text {rd }} \quad 4^{\text {th }}$

FORSCOM

Ft. Bragog

Ft. Devens

Ft. Hood

Ft. Lewis

\begin{tabular}{|c|c|c|c|}
\hline & $\begin{array}{l}.93 \\
.94 \\
.94 \\
.96\end{array}$ & $\begin{array}{l}.87 \\
.97 \\
.96 \\
.91\end{array}$ & $\begin{array}{l}1.14 \\
1.17 \\
1.06 \\
1.03\end{array}$ \\
\hline & $\begin{array}{l}.9425 \\
.0126\end{array}$ & $\begin{array}{l}.9275 \\
.0465\end{array}$ & $\begin{array}{l}1.10 \\
.0658\end{array}$ \\
\hline
\end{tabular}

TRADOC

Ft. Belvior

Ft. Gordon

Ft. Harris on

Ft. McClelien

Ft. Leonardwood
1.0133
.0467

1.0467

.8733

.8067

.9413

.1045
1.89

.91

.88

.9367

.9240

.0493
1.12

1.0233

1.0733

1.11

1.17

1.099

.0543
.9933

1.0267

1.0067

1.09

1.06

1.03

.0396

DAPCOM

Aberdeen $P G$

Letterkenny AD

MICOM

Ft. Monmouth

$$
\begin{array}{cccc}
.9467 & .8833 & 1.1133 & 1.0633 \\
1.2567 & .9733 & .08 & .8267 \\
1.01 & 1.0033 & 1.0733 & .03 \\
.9733 & .177 & 1.22 & 1.0133 \\
1.0467 & .9075 & 1.0967 & .9567 \\
.1424 & .1049 & .0994 & .1064
\end{array}
$$

$\begin{array}{lrrrr}\bar{x} & 1.0467 & .9075 & 1.0967 & .9567 \\ \mathrm{~s} & .1424 & .1049 & .0994 & .1064\end{array}$


EXIIII 5

SUMMARY OF SAMPLE BRANCH QUARTERLY

INDICES FY 77-FY 80 BASE:

NCO/ENL

$1^{\text {st }} \quad 2^{\text {nd }} \quad 3^{\text {rd }} \quad 4^{\text {th }}$

FORSCOM

\begin{tabular}{|c|c|c|c|c|c|}
\hline \multirow[t]{2}{*}{$\begin{array}{l}\text { Ft. Bragg } \\
\text { Ft. Devens } \\
\text { Ft. Hood } \\
\text { Ft. Lewis } \\
\text { Ft. Piley }\end{array}$} & & $\begin{array}{l}1.0067 \\
.8933 \\
.9933 \\
.9667 \\
.96\end{array}$ & $\begin{array}{l}1.03 \\
1.08 \\
1.0261 \\
.9967 \\
1.0367\end{array}$ & $\begin{array}{l}.9867 \\
1.11 \\
1.0333 \\
1.0267 \\
1.0333\end{array}$ & $\begin{array}{c}.9433 \\
.86 \\
.97 \\
1.0033 \\
.9767\end{array}$ \\
\hline & $s$ & $\begin{array}{l}.9640 \\
.0439\end{array}$ & $\begin{array}{c}1.0339 \\
.03\end{array}$ & $\begin{array}{r}1.0380 \\
.0447\end{array}$ & $\begin{array}{l}.9507 \\
.055\end{array}$ \\
\hline
\end{tabular}

TRADOC

Ft. Belvior

Ft. Gordon

Ft. Harrison

Ft. McClellen

Ft. Leonardwood

$\begin{array}{lllll} & 1.0033 & 1.0433 & 1.01 & .91 \\ & .0967 & .9467 & 1.04 & 1.08 \\ \text { en } & .9967 & 1.0333 & .8967 & .9333 \\ \text { wood } & .9833 & 1.0233 & .9433 & 1.01 \\ \bar{x} & .93 & 1.02 & 1.0233 & 1.0467 \\ \mathrm{~s} & .9620 & 1.0133 & .9827 & .9960 \\ & .0465 & .0383 & .0605 & .0727\end{array}$

DAPCOM

A berdeen $P G$

Letterkenney $A D$

MICCM

Ft. Monmouth

$\begin{array}{llrrc}\bar{x} & .9925 & .9883 & 1.0784 & 1.01 \\ \mathrm{~s} & .0457 & .0631 & .0497 & .1140\end{array}$




\section{EXHIBIT 6 \\ CORRELATION ANALYSIS}

OFFICERS BRANCHES

MA JCR COMMAND INDICES

\begin{tabular}{|c|c|c|c|c|c|c|}
\hline QRT. INDEX & FORSCOM & TRADOC & DARCOM & \multicolumn{3}{|c|}{ CORREIA TION } \\
\hline 1 & .9567 & .94 & .99 & FORSCOM-TRADOC & $\begin{array}{l}r= \\
r^{2}=\end{array}$ & $\begin{array}{l}.9864 \\
.9730\end{array}$ \\
\hline 2 & .9433 & .91 & .91 & \multirow[b]{2}{*}{ FORSCOM-DARCOM } & \multirow[b]{2}{*}{$\begin{array}{l}r= \\
r^{2}=\end{array}$} & \multirow[b]{2}{*}{$\begin{array}{l}.9198 \\
.8460\end{array}$} \\
\hline 3 & 1.08 & 1.11 & 1.09 & & & \\
\hline 4 & 1.0167 & 1.05 & 1.00 & TRADOC-DARCCM & $\begin{array}{l}r^{2}= \\
r^{2}=\end{array}$ & $\begin{array}{l}.9007 \\
.8112\end{array}$ \\
\hline \multicolumn{7}{|c|}{$\begin{array}{l}\text { NCO/ENL BRANCHES } \\
\text { MAJOR COMMAND INDICES }\end{array}$} \\
\hline 1 & .9833 & .96 & .95 & FORSCOM-TRADOC & $\begin{array}{l}r_{1}= \\
r^{2}=\end{array}$ & $\begin{array}{l}.6799 \\
.4622\end{array}$ \\
\hline 2 & 1.01 & 1.0033 & 1.00 & \multirow{2}{*}{ FORSCOM-DA RCOM } & \multirow{2}{*}{$\begin{array}{l}r= \\
r^{2}=\end{array}$} & \multirow{2}{*}{$\begin{array}{l}.7897 \\
.6237\end{array}$} \\
\hline 3 & 1.01 & 1.0250 & 1.03 & & & \\
\hline 4 & 1.00 & 1.0433 & 1.03 & TRADOC-DARCOM & $\begin{array}{l}r^{2}= \\
r^{2}=\end{array}$ & $\begin{array}{l}.9772 \\
.9548\end{array}$ \\
\hline
\end{tabular}


EXHIBIT ?

CORRELATION ANALYSIS

MEAN INDICES OF CLUB BRANCHES

FORSCOM

Officers NCO/ENL

Qrt

$1 \quad .9425$

$2 \quad .9275 \quad 1.0339$

31.10

41.005
TRADOC

Officers NCO/ENL

$r_{2}=.2866$

.9413

1.0993

1.03
DARCOM

Officers NCO/ENL

$.9620 \quad r_{2}=.1283$

1.0467

.9925

$r=.7224$
$r^{2}=.5218$

$.9075 \quad .9883$

$1.0967 \quad 1.0784$

$.9567 \quad 1.01$ 


\section{EXHIBIT 8}

SUMMARY OF MONTHLY SEASONAL INDICES

FY 77 - FY 80 BASE

-FORSCOM-

Officers

Branches

$\begin{array}{lllllll}0 & \mathrm{~N} & \mathrm{D} & \mathrm{J} & \mathrm{F} & \mathrm{M} & \mathrm{A}\end{array}$

M

J $\quad \mathrm{J}$

J A

$S$

$\begin{array}{lllllllllllll}\text { Ft. Bragg } & .85 & .86 & 1.10 & .79 & .87 & .96 & 1.03 & 1.05 & 1.34 & 1.18 & 1.01 & .93\end{array}$

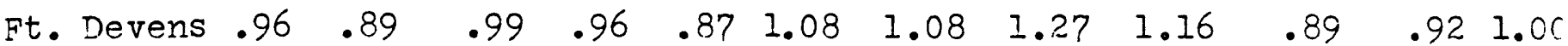

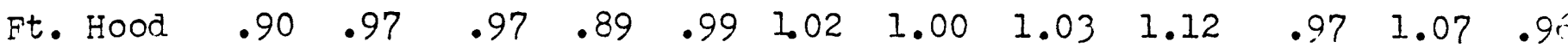

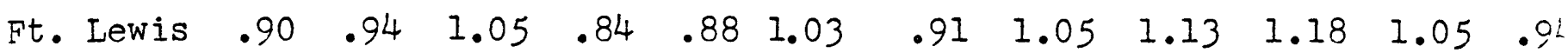

Ft. Riley Club Closure \& Subsequent Reopen

NCO/ENL

Branches

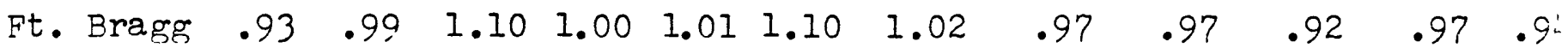

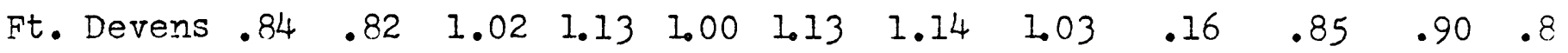

$\begin{array}{lllllllllllll}\text { Ft. Hood } & .94 & .96 & 1.08 & .94 & 1.03 & 1.11 & 1.05 & .99 & 1.06 & 1.02 & .99 & .9\end{array}$

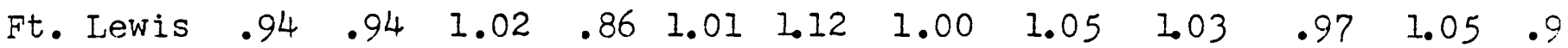

$\begin{array}{lllllllllllll}\text { Ft. Riley } & .99 & .96 & .93 & 1.05 & .94 & 1.12 & 1.08 & 1.02 & 1.00 & .98 & 1.04 & .9\end{array}$ -TRADOC-

Officers

Branches

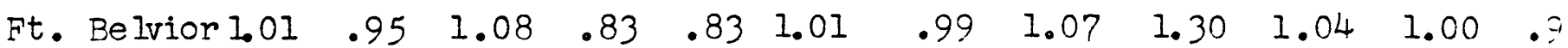

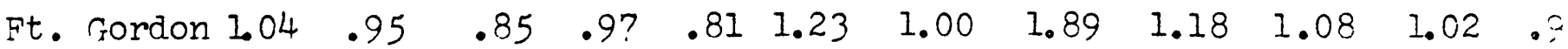

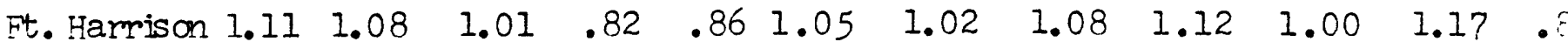

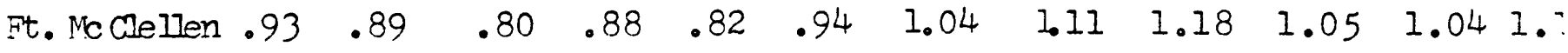

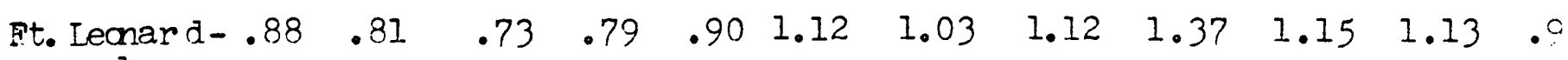
wood 
EXHIBIT 8 (continued)

NCO/ENL

Branches

Ft. Belvior

$F$ Ft Ft. McClellen 1.011 .10 Ft.Leonard- .95 1.02 wood

$0 \quad N$

D J F

M A

$M \quad J$

J A S

$\begin{array}{llllllllllll}.92 & .97 & 1.12 & .99 & 1.01 & 1.13 & 1.04 & .96 & 1.03 & .93 & .90 & .90\end{array}$ $\begin{array}{llllllllllll}.98 & .96 & .75 & .83 & .91 & 1.10 & 1.09 & 1.00 & 1.03 & 1.12 & 1.01 & 1.11\end{array}$

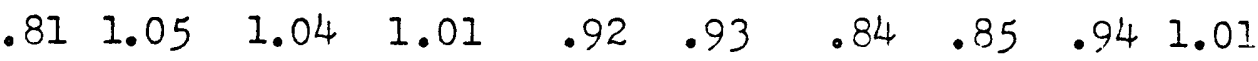

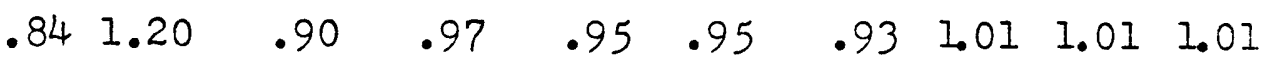
$\begin{array}{llllllllll}.82 & .83 & 1.07 & 1.16 & 1.09 & .95 & 1.03 & 1.06 & 1.03 & 1.05\end{array}$ -DARCOM -

Officers

Branches

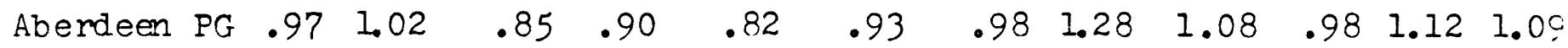
Dugway PG

Lette rkenny $A D$

MICOM .92 .92

1.371 .09

1.31 .80

Clubs Combined Mid-Period

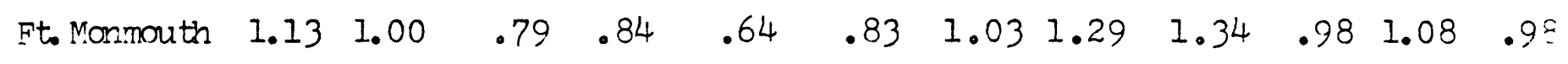
NCO/ENL

\section{Granches}

A berdeen $\mathrm{P}_{A}$

.951 .03

.851 .01

$.97 \quad 1.17$

1.131 .07

1.06

$.90 \quad .92 \quad .92$

Dugway $P G$

Letterkemy 1.0 $A D$

MICOM

$\begin{array}{llllllllllll}.97 & 1.01 & 1.07 & 1.15 & .94 & 1.01 & .98 & 1.02 & 1.02 & .95 & .99 & .85\end{array}$

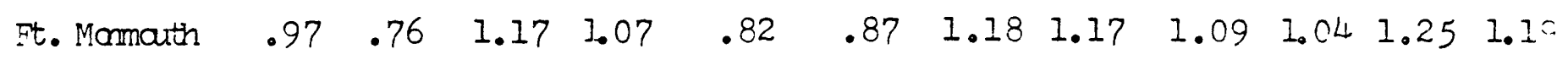




\section{FXHIBIT 9}

DEDUCED MACOM MONTHLY SEASONAL INDICES

FY 77-FY 80 BASE

$\begin{array}{llllllllllll}0 & \text { N } & \text { D } & \text { J } & \text { F } & \text { M } & \text { A } & \text { M } & \text { J } & \text { J } & \text { A } & \text { S }\end{array}$

FORSCOM

\begin{tabular}{|c|c|c|c|c|c|c|c|c|c|c|c|c|c|}
\hline Officers & $\mathrm{Br}$ & .90 & .91 & 1.02 & .87 & .90 & 1.02 & 1.00 & 1.11 & 1.18 & 1.05 & 1.01 & .95 \\
\hline $\mathrm{NCO} / \mathrm{ENL}$ & $\mathrm{Br}$ & .92 & .93 & 1.03 & .99 & .99 & 1.11 & 1.05 & 1.01 & 1.04 & .94 & .99 & .91 \\
\hline
\end{tabular}

\section{TRADOC}

$\begin{array}{llllllllllllll}\text { Officers } & \mathrm{Br} & .99 & .93 & .89 & .85 & .84 & 1.07 & 1.01 & 1.05 & 1.23 & 1.06 & 1.07 & .97 \\ \text { NCO/ENL } & \mathrm{Br} & .98 & 1.03 & .86 & .98 & .98 & 1.07 & 1.01 & .95 & .97 & .99 & .97 & 1.01\end{array}$

DARCOM

$\begin{array}{llllllllllllll}\text { Officers } & \mathrm{Br} & 1.09 & 1.00 & 1.03 & .90 & .82 & .98 & 1.02 & 1.20 & 1.06 & .87 & .93 & 1.07 \\ \text { NCO/ENL } & B r & .97 & .93 & 1.07 & 1.03 & .90 & 1.02 & 1.06 & 1.07 & 1.05 & .99 & 1.06 & .97\end{array}$




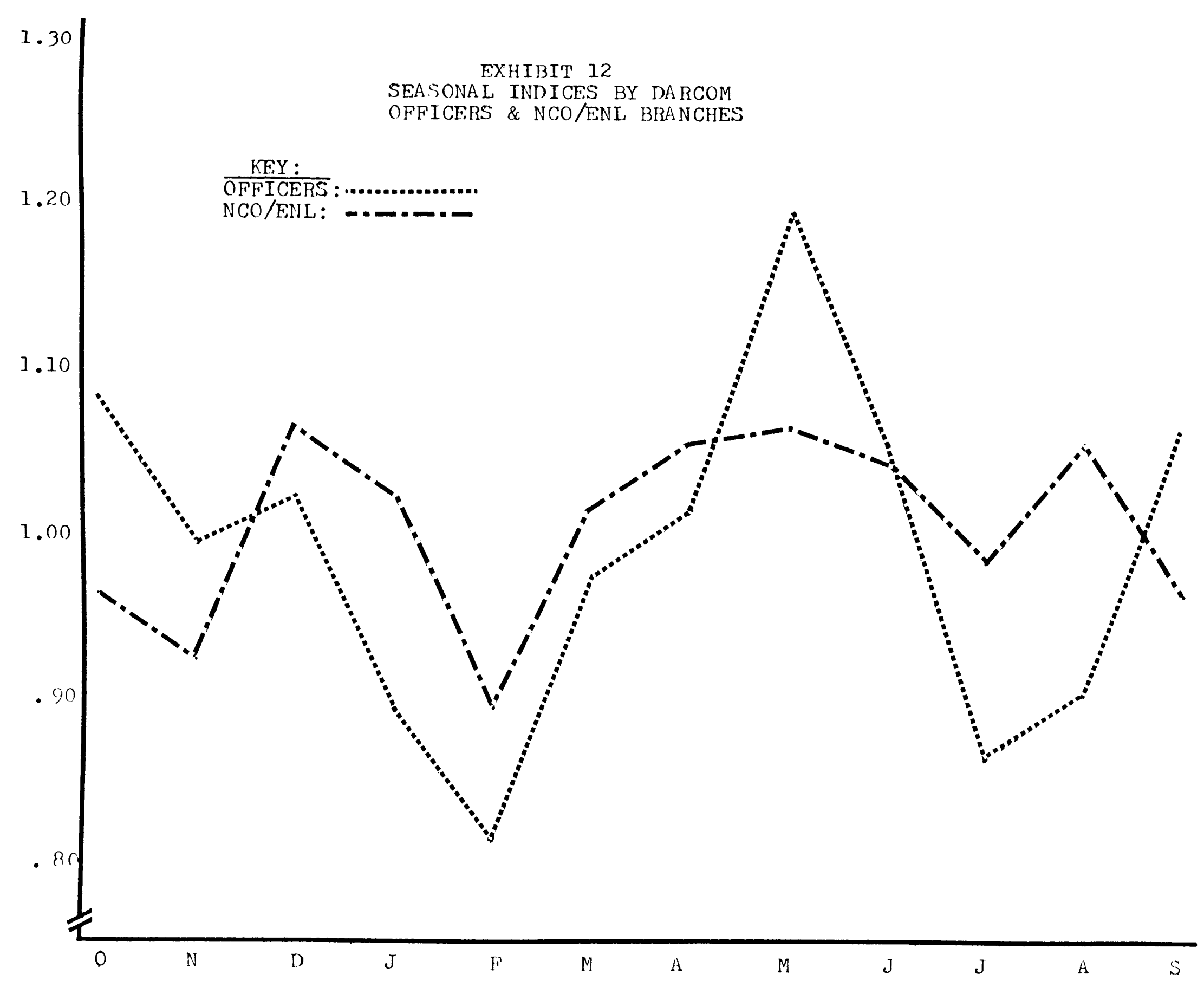




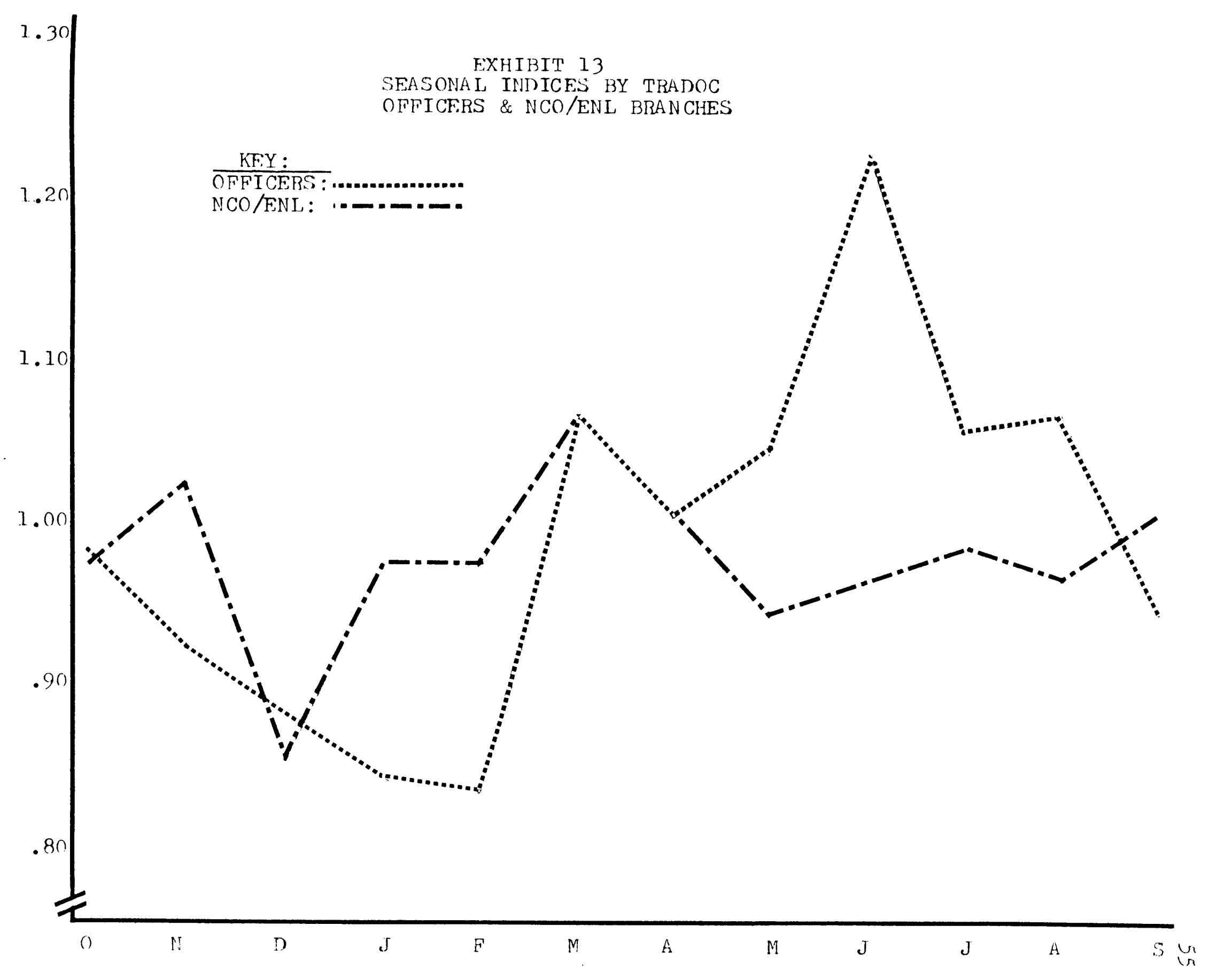




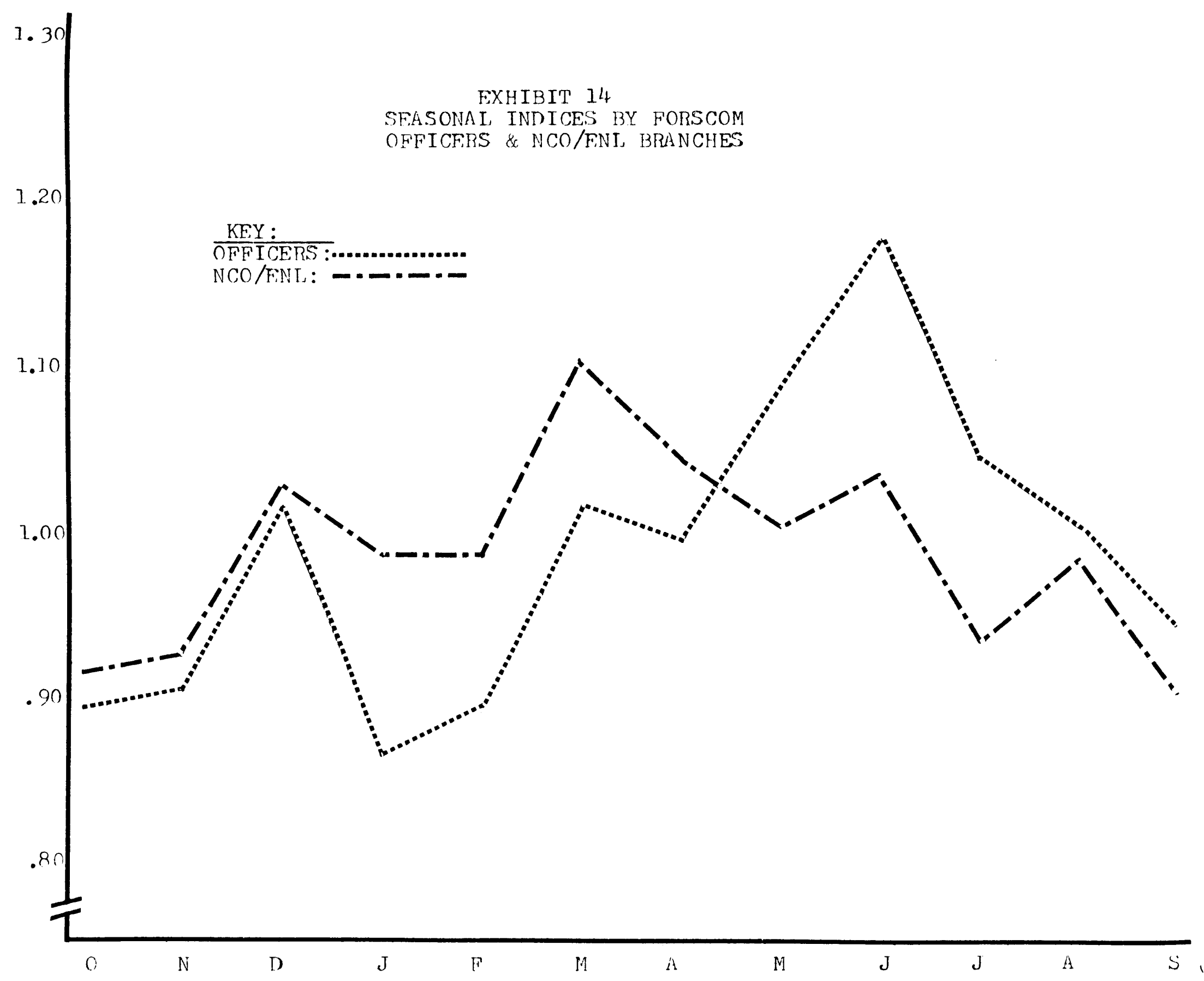




\section{TREND FACTOR}

Two methods are normally employed to determine the trend factor in the Time-Series Decomposition Method of Forecasting. The first is a visual fit of a trend line based on 3 to 6 month intervals of the moving average calculated for the seasonal index. Obviously, this technique is subject to the individual bias of the analyst doing the trending. However, a reasonably accurate factor can be deduced. Furthermore, it meets the fundamental premise of this project....simplicity.

The second technique employed is the Least Squares Method of fitting a trend line of the first degree. Naturally, trend calculations of the second degree may be more appropriate. However, these are outside the perimeters of this project. One concern was to reduce the amount of calculation involved in the preparation of the trend factor. To this end, trend projections were prepared from two different bases. The first was the most recent 12 month moving average which includes the current annual average of sales. The second was using the moving averages associated with 36 months of sales history, or 25 moving average points. Decause the Least squares method is non-statistical, error calculations were based on the sum squared errors ( $L S E$ ) and the mean square error (MSE). In order to test the validity 
of one trend over the other, projections were prepared for a six month period and tested against actual performance. Furthermore, several factors were calculated in an effort to identify a relationship that might indicate which trend base would be more accurate and require the fewest calculations. The factors calculated were: the mean and standard deviation of each trend base (i.e.) 25 moving average values and 12 moving average values. The sum squared error and the mean squared error as previously mentioned, and the deviation of the trend base mean from the current annual average (CAA).

The test was based on a forty-three percent sample of the branches contained in the basic analysis sample (i.e.) 13 of 30 . The results of this test are summarized in Exhibit 15. Upon reviewing these results one relationship seemed to indicate that the 12 point trend was preferable to the 25 point trend. This relationship is that of the mean square error to the deviation of the trend base mean from the current annual average. In all but for cases (30\%) the smaller the deviation of the trend base mean from the current annual average the smaller the mean square error, thus a more accurate projection. To determine the strength of this relationship, the mean square error and the deviation of the trend base mean from the current annual 
average was correlated. The results for the 25 point trend was an $r$ value of .2707 , indicating no meaningful relationship. However, the results for the 12 point trend was quite encouraging. An $r$ value of .8321 was observed. To test this resultant for significance based on the hypothesis that the population correlation coefficient $p$ is 0 in the uriverse from which the sample was drawn, the following was observed:

$\mathrm{H}_{\mathrm{O}}: \mathrm{p}=0$ Level of significance $5 \%$

$\mathrm{Ha}_{\mathrm{a}}: \mathrm{p} \neq 0 \quad \mathrm{n}=13$

Critical value \pm 2.201

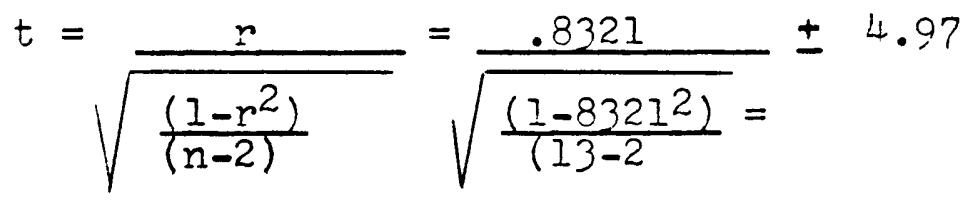

Since the computed $t$ value is 4.97 , considerably beyond the critical value, it can be concluded that the sample $r$ differs significantly from 0 , and the null hypothesis is rejected. Taking it one step further, the critical t for a 1,0 level of significance is \pm 3.106 , providing further indication of the relationship. Therefore, realistically speaking, if a manager calculates the mean for a 25 point trend base and a 12 point trend base, calculates the deviation of those mears from the current annual average, and selects the smallest deviation, he 
has a 70\% chance of selecting the 12 month base and thus a smaller mean square error and a more accurate trend projection. In other words, if he selects the 12 point trend base he has a 70\% chance of selecting the more accurate trend. This has the potential of saving a great deal of time and furthermore simplifying the entire process.

Conclusions: With a reasonable degree of accuracy a third altemative for trending is available to the manager. 
EXHIBIm 15

SUMMARY OF TREND COMPARISON

AND CORRELATION OF RESULTS

\begin{tabular}{|c|c|c|c|c|c|c|}
\hline Points of Trend & ESF. & MSE & $\bar{x}$ & CAA & $S$ & $(C A A-\bar{X})$ \\
\hline $\begin{array}{l}25 \\
12\end{array}$ & $\begin{array}{l}160.89 \\
153.34\end{array}$ & $\begin{array}{l}26.81 \\
25.55\end{array}$ & $\begin{array}{l}60.15 \\
60.94\end{array}$ & $\begin{array}{l}64.50 \\
64.50\end{array}$ & $\begin{array}{l}1.5185 \\
1.8352\end{array}$ & $\begin{array}{l}-4.35 \\
-3.56\end{array}$ \\
\hline $\begin{array}{l}25 \\
12\end{array}$ & $\begin{array}{l}748.68 \\
478.59\end{array}$ & $\begin{array}{r}124.78 \\
79.76\end{array}$ & $\begin{array}{l}29.82 \\
29.83\end{array}$ & $\begin{array}{l}34.00 \\
34.00\end{array}$ & $\begin{array}{l}1.80 \\
2.27\end{array}$ & $\begin{array}{l}-4.18 \\
-4.17\end{array}$ \\
\hline $\begin{array}{l}25 \\
12\end{array}$ & $\begin{array}{r}2533 \cdot 52 \\
25306.42\end{array}$ & $\begin{array}{r}422.25 \\
4217.73\end{array}$ & $\begin{array}{l}163.01 \\
146.96\end{array}$ & $\begin{array}{l}122.80 \\
122.80\end{array}$ & $\begin{array}{l}21.88 \\
18.38\end{array}$ & $\begin{array}{l}40.21 \\
24.16\end{array}$ \\
\hline $\begin{array}{l}25 \\
12\end{array}$ & $\begin{array}{l}4517.30 \\
4093.63\end{array}$ & $\begin{array}{l}752.89 \\
682.27\end{array}$ & $\begin{array}{l}142.27 \\
136.17\end{array}$ & $\begin{array}{l}137.60 \\
137.60\end{array}$ & $\begin{array}{l}7.02 \\
2.88\end{array}$ & $\begin{array}{r}4.67 \\
-1.43\end{array}$ \\
\hline $\begin{array}{l}25 \\
12\end{array}$ & $\begin{array}{r}1026.95 \\
247.56\end{array}$ & $\begin{array}{c}171.15 \\
4126\end{array}$ & $\begin{array}{l}15.00 \\
15.40\end{array}$ & $\begin{array}{l}19.40 \\
19.40\end{array}$ & $\begin{array}{l}1.8451 \\
2.03\end{array}$ & $\begin{array}{l}-4.40 \\
-4.00\end{array}$ \\
\hline $\begin{array}{l}25 \\
12\end{array}$ & $\begin{array}{l}322.86 \\
127.04\end{array}$ & $\begin{array}{l}53.81 \\
21.17\end{array}$ & $\begin{array}{l}37.82 \\
36.69\end{array}$ & $\begin{array}{l}34.30 \\
34.30\end{array}$ & $\begin{array}{l}3.82 \\
2.65\end{array}$ & $\begin{array}{l}3.82 \\
2.39\end{array}$ \\
\hline $\begin{array}{l}25 \\
12\end{array}$ & $\begin{array}{l}340.37 \\
266.95\end{array}$ & $\begin{array}{l}56.72 \\
44.99\end{array}$ & $\begin{array}{l}40.65 \\
42.57\end{array}$ & $\begin{array}{l}43.10 \\
43.10\end{array}$ & $\begin{array}{r}2.44 \\
.99\end{array}$ & $\begin{array}{l}-2.45 \\
-.53\end{array}$ \\
\hline $\begin{array}{l}25 \\
12\end{array}$ & $\begin{array}{l}350.49 \\
933.85\end{array}$ & $\begin{array}{r}58.41 \\
155.64\end{array}$ & $\begin{array}{l}33.68 \\
38.20\end{array}$ & $\begin{array}{l}43.4 \\
43.4\end{array}$ & $\begin{array}{l}5.1383 \\
3.7557\end{array}$ & $\begin{array}{l}9.72 \\
5.20\end{array}$ \\
\hline $\begin{array}{l}25 \\
12\end{array}$ & $\begin{array}{r}649.08 \\
1143.90\end{array}$ & $\begin{array}{l}108.18 \\
190.65\end{array}$ & $\begin{array}{l}23.76 \\
21.57\end{array}$ & $\begin{array}{l}18.5 \\
18.5\end{array}$ & $\begin{array}{l}2.65 \\
2.10\end{array}$ & $\begin{array}{l}-5.26 \\
-3.07\end{array}$ \\
\hline $\begin{array}{l}25 \\
12\end{array}$ & $\begin{array}{r}214.14 \\
1182.54\end{array}$ & $\begin{array}{r}35.69 \\
197.09\end{array}$ & $\begin{array}{l}57.96 \\
51.90\end{array}$ & $\begin{array}{l}41.9 \\
41.9\end{array}$ & $\begin{array}{l}7.5260 \\
5.9261\end{array}$ & $\begin{array}{l}-16.06 \\
-10.00\end{array}$ \\
\hline $\begin{array}{l}25 \\
12\end{array}$ & $\begin{array}{l}3718.04 \\
2813.98\end{array}$ & $\begin{array}{l}619.67 \\
468.99\end{array}$ & $\begin{array}{l}22.50 \\
28.26\end{array}$ & $\begin{array}{l}34.6 \\
34.6\end{array}$ & $\begin{array}{l}7.0560 \\
6.2091\end{array}$ & $\begin{array}{r}12.10 \\
6.34\end{array}$ \\
\hline $\begin{array}{l}25 \\
12\end{array}$ & $\begin{array}{l}4457.13 \\
2701.56\end{array}$ & $\begin{array}{l}742.85 \\
450.26\end{array}$ & $\begin{array}{l}49.66 \\
42.95\end{array}$ & $\begin{array}{l}42.5 \\
42.5\end{array}$ & $\begin{array}{l}7.1005 \\
2.1288\end{array}$ & $\begin{array}{l}-? .16 \\
-.45\end{array}$ \\
\hline $\begin{array}{l}25 \\
12\end{array}$ & $\begin{array}{l}560.10 \\
763.05\end{array}$ & $\begin{array}{r}93.35 \\
127.17\end{array}$ & $\begin{array}{l}51.31 \\
55.85\end{array}$ & $\begin{array}{l}6 I .4 \\
61.4\end{array}$ & $\begin{array}{l}5.2466 \\
3.3209\end{array}$ & $\begin{array}{r}10.09 \\
5.55\end{array}$ \\
\hline
\end{tabular}


EXHIBIT 15 (continued)

-CORRELATION-

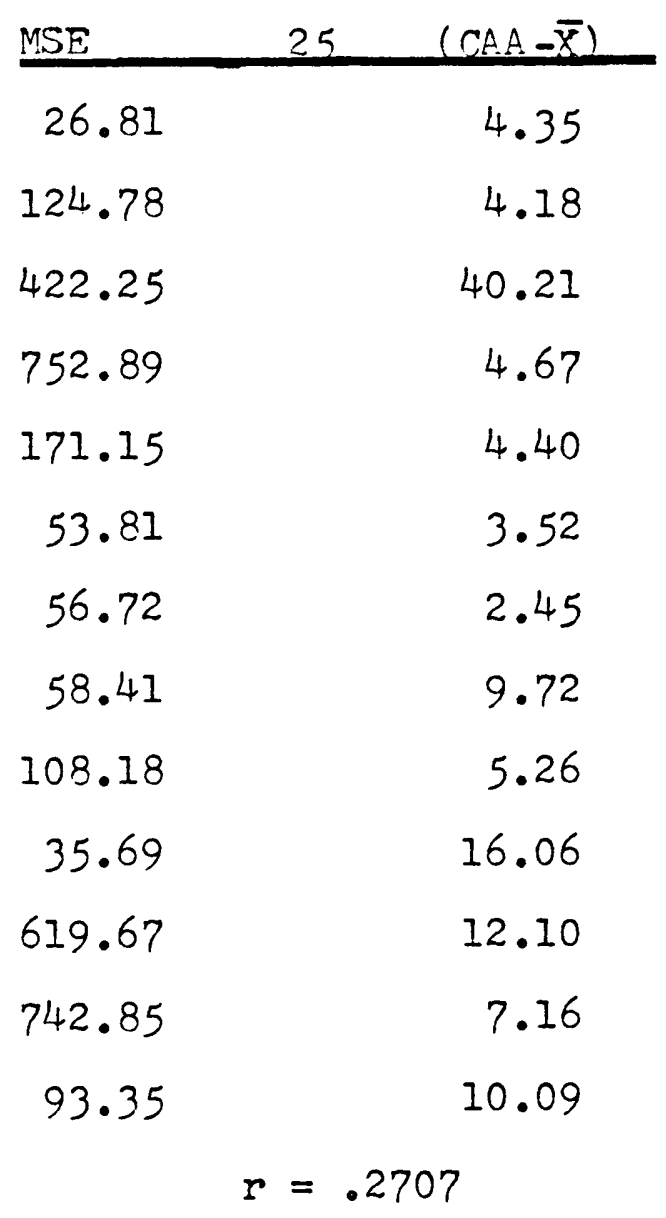

MSE

$\begin{array}{rr}25.55 & -3.56 \\ 79.76 & -4.17 \\ 4217.73 & 24.16 \\ 682.27 & -1.43 \\ 41.26 & -4.00 \\ 21.17 & 2.39 \\ 44.49 & .53 \\ 155.64 & 5.20 \\ 190.65 & -3.07 \\ 197.69 & -10.00 \\ 468.99 & 6.34 \\ 450.26 & -.45 \\ 127.17 & 5.55\end{array}$

$r=.8321$ 


\section{CYCLICAL FACTOR}

The primary intent of this analysis was to determine if any relationship existed between the general business cycle and the cycle experienced in club sales. The first consideration was the calculation of the club cyclical factors. For this aspect of the analysis the major command quarterly totals were used. Calculation of the cyclical factor was based upon the ratio of the trend value to the moving average which produced an index of cyclical movement.

The first contention was that for this factor to be significant in terms of this study, the cyclical movement would also have to be significant relative to its range of movement. Normally, the cyclical factor requires between 2 to 5 years of sales history before it becomes evident in terms of repeating cycles. Likewise, the cyclical factor is often excluded from short term models because of lack of movement relative to the short term forecast horizon. As mentioned previously, this analysis is based on four years of sales history.

The second contention was that because the military club and its market is relatively isolated from the general business community, club sales do not experience sigrificant cyclical movement relative to the general business cyclical. Consequently, the cyclical component could be eliminated from 
this time series forecast in keeping with the overriding premise of simplicity.

The cyclical factors were computed for each major command by category (i.e.) officer and NCO/ENL branches. A summary of these factors are provided in Exhibit 16. The mean and standard deviation was calculated for each series. The degree of variability for each series is very small. Likewise, the means are clustered very close to one another. Based upon these results it can be concluded that the individual indices of the cyclical factor differ very little from one another. Statistical testing produces the same results when the means are tested against the population mean. Test criteria established was a level of significance of $1 \%$ with the hypotheses that the means were equal. No statistical difference was noted. These results support the first contention. Although a cyclical factor does exist, it is not significant in terms of the period studied which in turn indicates that its importance, for the short term forecasting, is relatively insignificant.

In order to test the second contention, three widely accepted indices of the general business cyclical were obtained and correlated to the individual major command indices by 
category. The composite index of economic indicators consisting of 12 leading, 4 coincident and 6 lagging indicators, published monthly by the Department of Commerce, was used to test the major command factors. The results of the correlation is summarized in Exhibit 17. As can be noted, none of the correlation coefficients can be considered significant. The net result is that there is no meaningful relationship of the cyclical factors for the major commands to the general business cycle, therefore supporting the stated contention. However, the actual degree of isolation experienced by the military community is a subject that should warrant additional research, especially if long range models of sales forecasting are eventually adopted.

In conclusion, it can be surmised that, for the short term, the cyclical factor can be disregarded in the formation of this forecasting procedure. 
EXHIBIT 16

SUMMARY OF MA JOR COMMAND

CYCLICAL FACTORS

FORSCOM

FY $77 \quad \frac{Q r t}{1}$

2

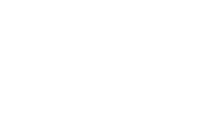

FY 78

FY 79

FY 80

$\begin{array}{llcc}1 & .99 & 1.06 \\ 2 & .99 & 1.02 \\ 3 & .99 & 1.02 \\ \overline{\mathrm{x}}= & .9992 & \overline{\mathrm{x}}=1.0085 \\ \mathrm{~s}= & .02 & \mathrm{~s}=.03\end{array}$

$$
.98
$$$$
1.00
$$$$
.99
$$$$
2
$$$$
3
$$

4

1

2

3

4
TRADOC

Off

1.00

1.00

1.00

1.00

1.00

1.00

1.00

1.00

1.00

.99

.99

1.00

1.01

$\bar{x}=.9992$

$s=.005$
NCO/ENL

1.01

1.02

1.03

1.03

1.00

.98

.96

.95

.96

.96

1.00

1.04

1.07

$\bar{x}=1.0009$

$s=.04$
DA RCOM

Off NCO/ENL

$1.05 \quad 1.02$

$1.01 \quad 1.02$

$.99 \quad 1.01$

$.98 \quad 1.01$

.981 .00

$.98 \quad .98$

$.98 \quad .98$

$.98 \quad .96$

$1.00 \quad .97$

$1.00 \quad .99$

$1.01 \quad 1.00$

$1.02 \quad .92$

$1.01 \quad 1.03$

$\overline{\mathrm{x}}=.9992 \quad \overline{\mathrm{x}}=.9915$

$s=.02 \quad s=.03$ 


\section{EXHIBIT 17}

SUMMARY OF ECONOMIC CYCLICAL INDICATORS

$\begin{array}{llll}\text { CY Qrt } & \text { Leading } & \text { Coincident } & \text { Lagging } \\ 2^{\text {nd }} 77 & 130.2 & 129.6 & 124.6 \\ 3^{\text {rd } 77} & 131.8 & 130.8 & 127.9 \\ 4^{\text {th } 77} & 134.6 & 133.0 & 132.1 \\ 1^{\text {st } 78} & 134.2 & 134.1 & 137.2 \\ 2^{\text {nd } 78} & 137.2 & 138.2 & 141.8 \\ 3^{\text {rd }} 78 & 137.4 & 139.6 & 146.8 \\ 4^{\text {th }} 78 & 143.6 & 144.5 & 151.9 \\ 1^{\text {st } 79} & 143.3 & 145.6 & 158.1 \\ 2^{\text {nd }} 79 & 139.9 & 144.9 & 162.7 \\ 3^{\text {rd }} 79 & 139.7 & 144.9 & 167.3 \\ 4^{\text {th }} 79 & 137.4 & 144.8 & 178.2 \\ 1^{\text {st }} 80 & 133.5 & 144.7 & 183.4 \\ 2^{\text {nd }} 80 & 124.1 & 138.0 & 182.8\end{array}$

SUMMARY OF CORRELATION COEFFICIENTS FCR:

CYCLICAL INDICATORS (VS) ARMY CLUB SALES CYCLICAL FACTORS

\begin{tabular}{llllllll} 
& \multicolumn{2}{c}{ FORSOM } & \multicolumn{2}{c}{ TRADOC } & \multicolumn{2}{c}{ DARCOM } \\
Composite Index & & Off & NCO & off & NCO & Off & NCO \\
\hline Leading Indicators $(r)$ & .4097 & -.3563 & -53.45 & -.3125 & .5792 & -.1258 \\
Coincident Indicators $(r)$ & .1551 & -.1095 & -.3480 & -.5537 & -.3106 & .1841 \\
Lagging Indicators $(r)$ & -.0404 & .2062 & -.0761 & .0398 & .0550 & -.04631
\end{tabular}




\section{Operational Data}

The data for this segment are universally accepted as fundamental to forecasting for a food and beverage operation. The primary concerm is the formatting of these elements in such a way as to present an easily understood, and workable, format. The elements to be incorporated are:

a. Meal period tumover by month.

b. Number of covers served by meal period, for the month.

c. Number of operational days in period.

d. Average check by meal period, monthly.

e. Sales mix data.

f. Beverage sales by seat for forecast period.

Judgmental Forecast Data

This category consists of a series of questions that will be formatted for the forecaster to answer. The result of the answers will be related to the statistical and operational data with adjustments made as deemed necessary. The major elements are as follows:

1. Is the installation population going to change significantly during the forecast period?

- If so, by how much?

- What's your best estimate of the impact on the club? 
2. Are there any significant changes in the membership totals, composition or demographics recently that may impact on the forecast period?

- What are the sales per member for the historic period used as forecast kase to date?

- Are there any significant trends?

3. Will any of the major units on the installation deploy or participate in field exercises during the forecast period?

4. Are there any significant events, external to the club, planned for the forecast period?

- On the installation?

- In the local community?

5. Are there any major changes in the competitive environment?

- On the installation?

- In the local community?

6. Are there any plans to change prices during the forecast period?

- If so, what will be the impact?

- What is the impact of inflation?

7. Are there any changes in the sales mix?

- Is there an impact? 
8. Are there any major events, promotions or changes planned or anticipated during the forecast period?

- What is the expected impact?

9. What is the most prevalent complaint?

- What is being done about it?

- Will it effect the forecast?

10. Are there any other factors that may effect the forecast?

- Is there an impact?

These factors are to be weighed, expressed as a percentage impact, and adjustments made to the statistical and operational forecast. The net result will be a forecast formulated based on all three levels of forecasting. 
V. GRAPHIC PRESENTATION OF WORKSHEETS AND INSTRUCTIONS 
Worksheet Development

In the development of the first worksheet, which contains the basic information for the calculation of the seasonal and trend elements of the decomposed time-series, there were two problems.

The first was how to simplify the moving average calculation so that it could be computed on a basic calculator. The approach selected was to break down the components into the moving total and then the moving average. To insure the correct moving total, a spacing template was devised to prevent the inclusion of too few or too many values.

The second problem was the simplification of the least squares method of fitting a trend line of the first degree. The coded $x$ value technique is a widely accepted method of simplifying the calculation of the linear equation. Because this technique eliminates $x$ values (i.e.) $\Sigma x=0$ and $\bar{x}=0$, it was selected for inclusion in this model. However, the coding process for even and odd number $x$ values was seen as a possible difficulty. Therefore, two $x$ value scales were devised. One providing the $x$ values for an odd number of values and the other for an even number of values. These scales are designed 
in such a way so that they line up with the sales values "Y" for the completion of the $x y$ calculations. Another significant consideration that led to the designing of these scales was if the trend line is up dated quarterly, the even and odd number of values will altemate consequently complicating the calculations.

Worksheet 2 summarizes the results of the first worksheets in terms of the seasonal factor. The first segment provides a space for recording the seasonal indices calculated and then the averaging of those indices. The next portion provides space for the plotting of the annual seasonal curve, this is considered optional. The lower segments provide for the final calculations involved in the calculation of the trend factor. This is essentially a fill-in-the-blank process. Once again, the simplified equations are provided and all that is required is multiplication and addition. The final segment brings it together for the calculation of the statistically based forecast.

Worksheets 3 and 4 provide the format for the operational forecast. This process begins with a review of the general sales mix, followed by the beverage sales mix, which is in turn followed by a meal period analysis. The intent here is 
to provide for the comparison of sales for the current month, the same month a year ago and the previous month. This is followed by the operational forecast by meal period. Spaces have been provided for each relationship necessary for these calculations. Additionally, space is provided for the figuring of the quarterly meal period forecast. The same approach is employed for the beverage sales forecast.

The last segment of worksheet 4 provides for the summarization of the food and beverage forecast and its comparison with the statistically based forecast.

Worksheet 5 lists those basic subjective factors that must be considered by management in the development of a forecast. These factors take the form of 10 questions with notation space. The forecaster is asked to quantify as much as possible (i.e.) percentage increase or decrease and impact. Worksheet 6 develops the final forecast considering the statistical, food and beverage and judgmental adjustments. The lower portion of worksheet 6 provides for forecast evaluation. The worksheets and templates are presented in the following section. 
WORKSHEETS AND TEMPLATES 
WORKSHEET I

\begin{tabular}{|c|c|c|c|c|c|c|c|c|}
\hline & $\begin{array}{l}\text { Column } 1 \\
\text { Sales } \\
\text { Figures }\end{array}$ & $\begin{array}{c}\text { Column } 2 \\
12 \text { Month } \\
\text { Moving } \\
\text { Total } \\
\end{array}$ & $\begin{array}{l}\text { Column } 3 \\
12 \text { Month } \\
\text { Moving A vo } \\
\text { Col } 2 \div 12\end{array}$ & $\begin{array}{c}\text { Column } 4 \\
\text { Seasonal } \\
\text { Index } \\
\operatorname{col} 1 \div \operatorname{col} 3\end{array}$ & $\begin{array}{l}\text { Column } 5 \\
\text { code choice } \\
(x 00) \text { (xioo } \\
\text { Mon Yr }\end{array}$ & $\begin{array}{c}\text { Column } 6 \\
\text { Coded Mbv Aut } \\
\text { From col } 3 \\
Y\end{array}$ & $\begin{array}{c}\text { Column } 7 \\
\mathrm{XY} \\
\end{array}$ & $\begin{array}{c}\text { Column } 8 \\
x^{2} \\
\end{array}$ \\
\hline 11 & & & & & 1 & & & \\
\hline 2 & & & I & 8 & 2 & & & \\
\hline 3 & & & & & 3 & & & \\
\hline 4 & & & 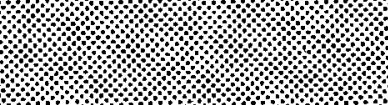 & 8 & 4 & & & \\
\hline$\frac{5}{6}$ & & & & & 5 & & & \\
\hline 6 & & & & & 6 & & & \\
\hline 7 & & & & & 7 & & & \\
\hline 8 & & & & & $\varepsilon$ & & & \\
\hline 9 & & & & & $g$ & & & \\
\hline 10 & & & & & 1 & & & \\
\hline 11 & & & & & 1 & & & \\
\hline 12 & & & & & 1 & & & \\
\hline 13 & & & & & 1 & & & \\
\hline 14 & & & & & 1 & & & \\
\hline 15 & & & & & 1 & & & \\
\hline 16 & & & & & 1 & & & \\
\hline 17 & & & & & 1 & & & \\
\hline 18 & & & & & 1 & & & \\
\hline 19 & & & & & I & & & \\
\hline 20 & & & & & 2 & & & \\
\hline 21 & & & & & 2 & & & \\
\hline 22 & & & & & 2 & & & \\
\hline 23 & & & & & 2 & & & \\
\hline 24 & & & & & 2 & & & \\
\hline 25 & & & & & 2 & & & \\
\hline 26 & & & & & & & & \\
\hline 27 & & & & & $E^{\prime}$ & & & \\
\hline 28 & & & & & 2 & & & \\
\hline 29 & & & & & 2 & & & \\
\hline 30 & & & & & 3 & & & \\
\hline 31 & & & & & 3 & & & \\
\hline 32 & & & & & 3 & & & \\
\hline 33 & & & & & 3 & & & \\
\hline 34 & & & & & 3 & & & \\
\hline 35 & & & & & 3 & & & \\
\hline 36 & & & & & 3 & & & \\
\hline 37 & & & & & . & & & \\
\hline 38 & & & & & 3 & & & \\
\hline 39 & & & & & 3 & & & \\
\hline 40 & & & & & 4 & & & \\
\hline 41 & & & & & 4 & & & \\
\hline 42 & & & & & 4 & & & \\
\hline 43 & & & & & 4 & & & \\
\hline 44 & & & & & 4 & & & \\
\hline 45 & & & & & 4 & & & \\
\hline 46 & & & & & 4 & & & \\
\hline 47 & & & & & 4 & & & \\
\hline 48 & & & & & IL & & & \\
\hline 49 & & & & & L & & & \\
\hline 50 & & & & & 5 & & & \\
\hline 51 & & & & & $T_{5}$ & & & \\
\hline 52 & & & & & 5 & & & \\
\hline 53 & & & & & 5 & & & \\
\hline 54 & & & & & fs & $4]^{-}$ & & \\
\hline 35 & & & & & t. & & & \\
\hline 56 & & & & & $i$ & & & \\
\hline 57 & & & & & ts & & & \\
\hline 58 & & & & & to & & & \\
\hline
\end{tabular}


WORKSHEET 2

Seasonal Index

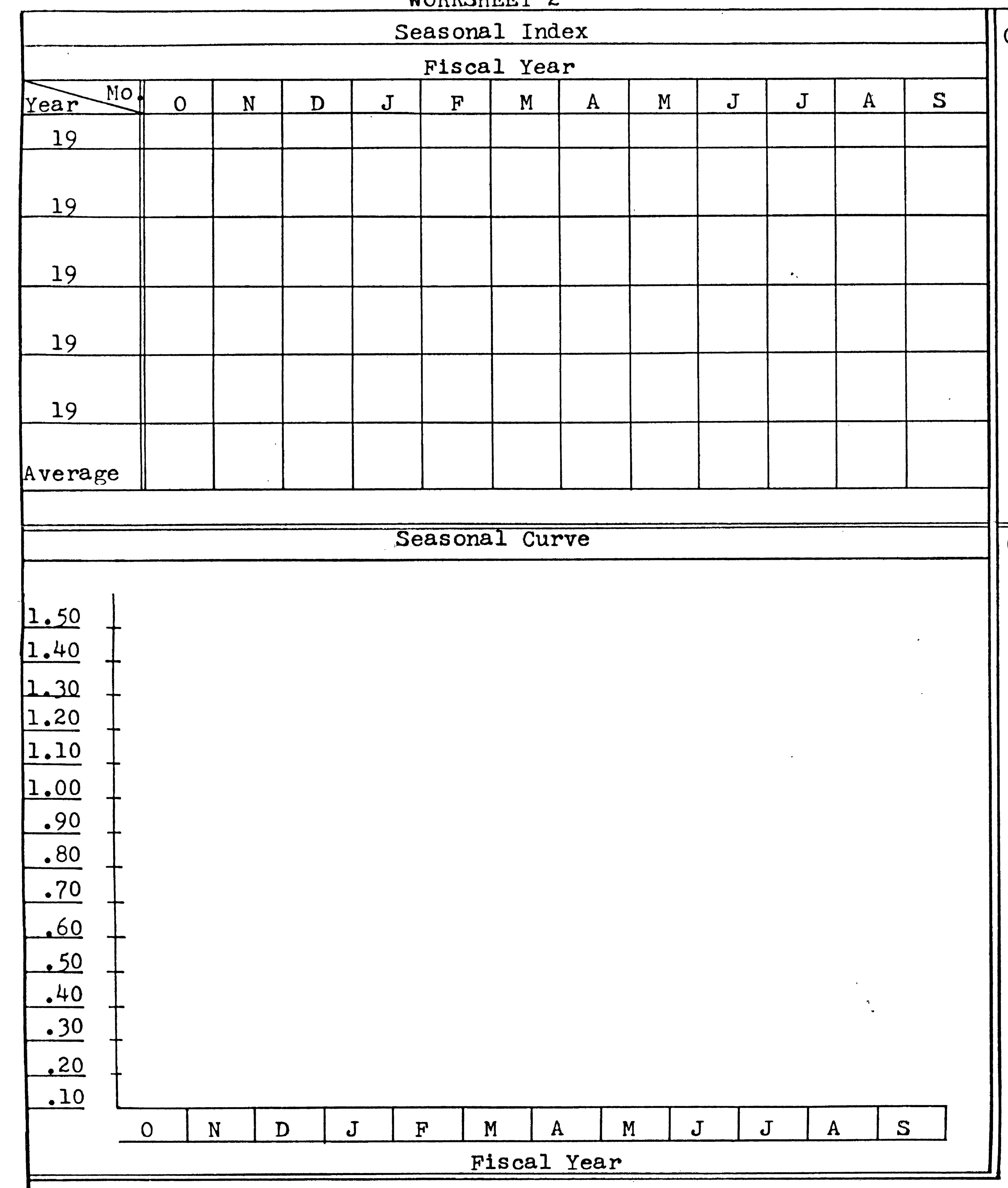

Trend Work Space

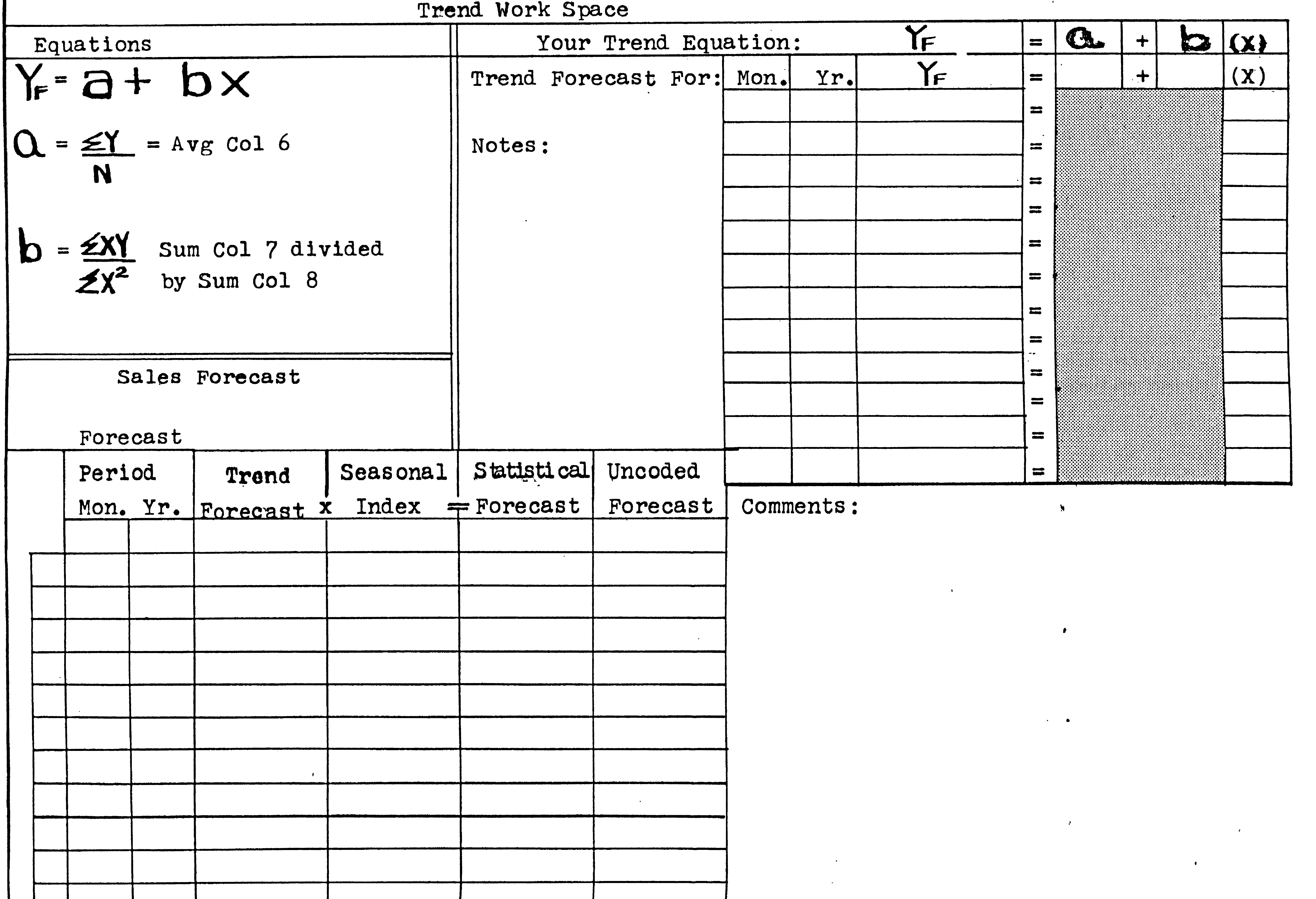




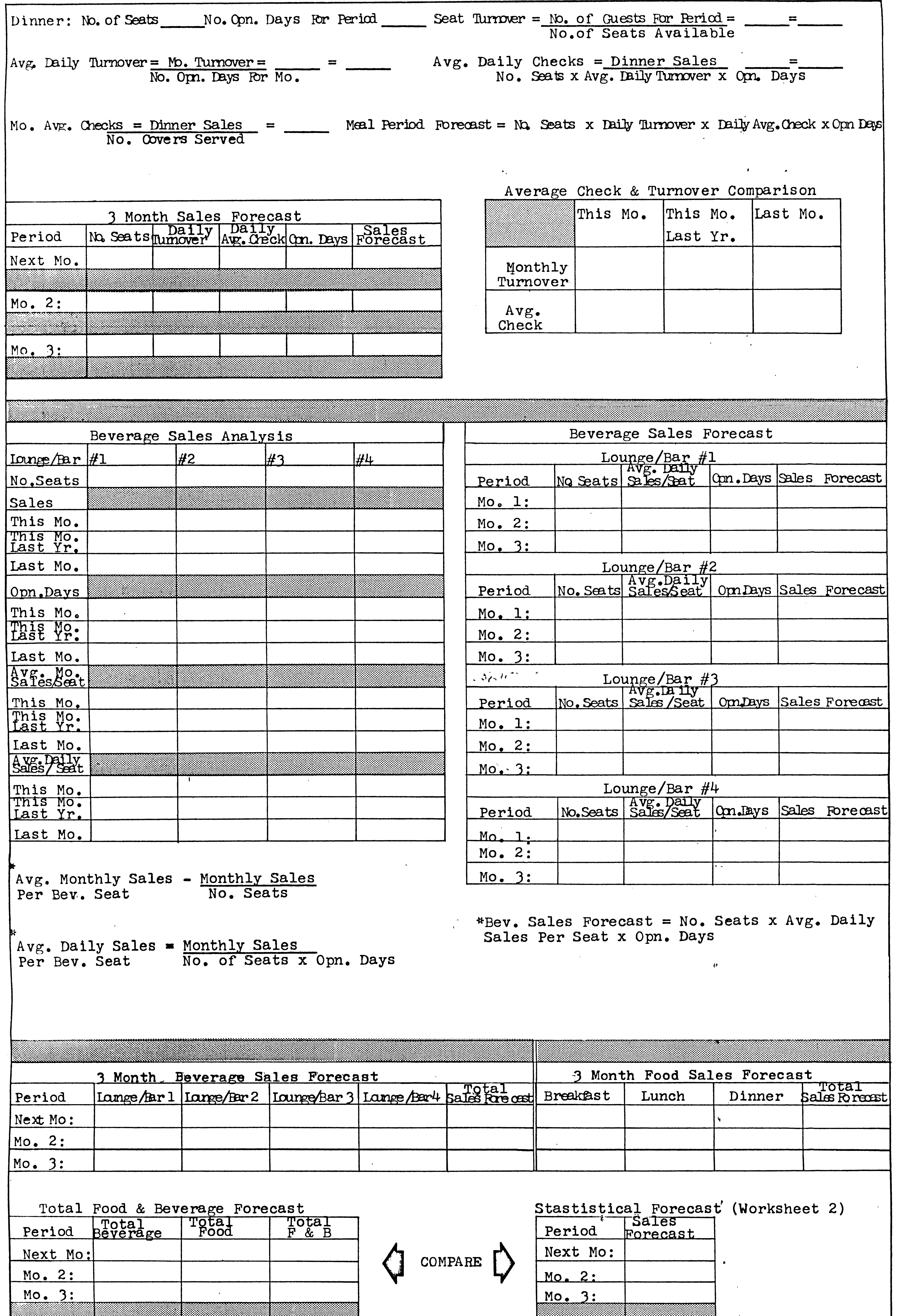


1. Is the installation population going to change significantly during the forecast period?

- If so, by how much?

- What's your best estimate of the impact on the club?

2. Are there any significant changes in the membership totals, composition or demographics recently that may impact on the forecast period?

- What are the sales per member for the historic period used as forecast base to date?

- Are there any.significant trends?

3. Will any of the major units on the installation deploy or participate in field exercises during the forecast period?

4. Are there any significant events, external to the club, planned for the forecast period?

- On the installation?

- In the local community?

5. Are there any major changes in the competitive environment?

- On the installation?

- In the local community?

6. Are there any plans to change prices during the forecast period?

- If so, what will be the impact?

- What is the impact" of inflation?

7. Are there any changes in the sales mix?

- Is there an impact?

8. Are there any major events, promotions or changes planned or anticipated during the forecast period?

- What is the expected impact?

9. What is the most prevalent complaint?

- What is being done about it?

- Will it effect the forecast?

10. Are there any other factors that may effect the forecast?

- Is there an impact?

Notes \& Comments: 
Final Forecast

\begin{tabular}{|l|l|l|l|l|}
\hline Period & Statistical Forecast & F \& B Forecast & Judgment Ad justments \% & Final Forecast \\
\hline Next Month & & & & \\
\hline Month 2 & & & & \\
\hline Month 3 & & & & \\
\hline Month 4 & & & & \\
\hline Month 5 & & & & \\
\hline Month 6 & & & & \\
\hline Month 7 & & & & \\
\hline Month 8 & & & & \\
\hline Month 9 & & & & \\
\hline Month 10 & & & & \\
\hline Month 11 & & & & \\
\hline Month 12 & & & & \\
\hline
\end{tabular}

Forecast Evaluation

\begin{tabular}{|l|l|l|l|l|l|}
\hline Period & Actual Sales & Forecast Sales & $\begin{array}{c}\text { Error } \\
\text { Act-Forecas ted }\end{array}$ & $\begin{array}{l}\text { Percentage Error } \\
\text { Act-Forecast -Act }\end{array}$ & Error Squared \\
\hline Month 1 & & & & & \\
\hline Month 2 & & & & & \\
\hline Month 3 & & & & & \\
\hline Month 4 & & & & & \\
\hline Month 5 & & & & \\
\hline Month 6 & & & & \\
\hline Month 7 & & & & & \\
\hline Month 8 & & & & & \\
\hline Month 9 & & & & \\
\hline Month 10 & & & Mean Error & \\
\hline Month 11 & & & Squared & \\
\hline Month 12 & & & & \\
\hline \begin{tabular}{l} 
Total \\
\hline
\end{tabular} \\
\hline Notes \& Comments & & & & \\
\hline
\end{tabular}




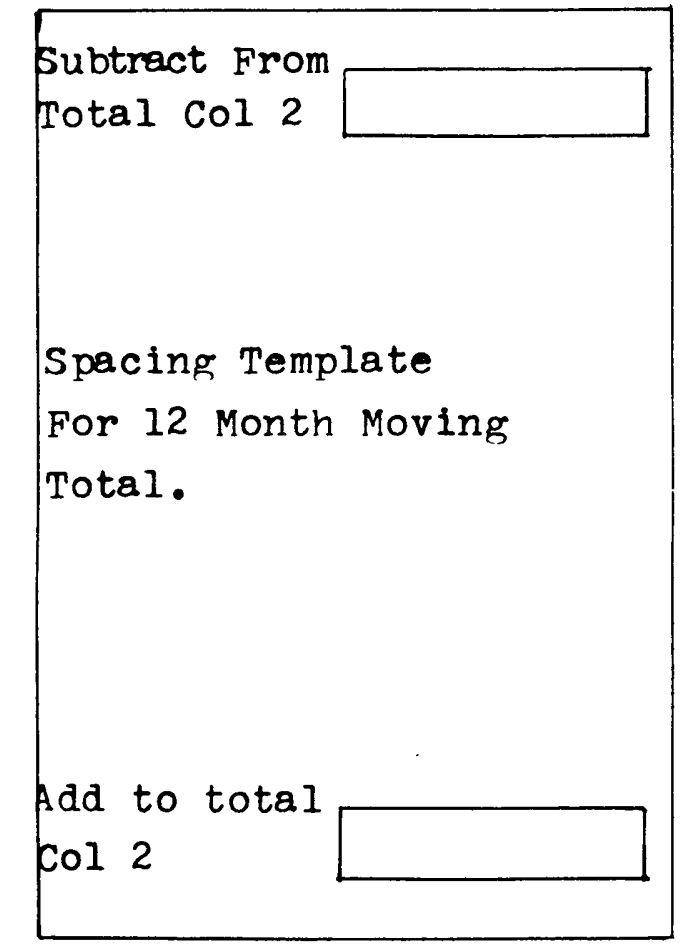


CUT OUT SCALES ALONG DARK LINES

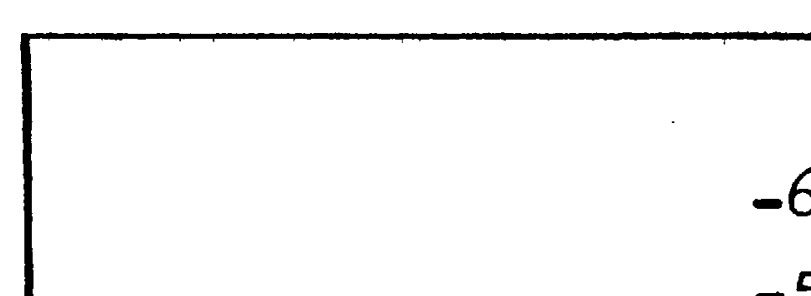

$-59$

$-57$

$-55$

$-53$

$-51$

$-49$

$-47$

$-45$

$-43$

$-41$

$-39$

$-37$

$-35$

$-33$

$-31$

$-29$

$-27$

$-25$

$-23$

$-21$

$-19$

$-17$

$-15$

$-13$

$-11$

$-9$

$x$ Value Scale

for EVEN Number - 7

of Moving Average - 5

Totals. $\quad-3$

Totals.

$-3$

$-2$

Place Arrow

and Zerö on

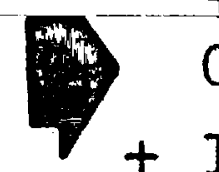

Center value (i.e.) +2

equal Number

$+3$

A bove and Below +4

$+5$

$+6$

$+7$

$+8$

$+9$

$+10$

$+11$

$+12$

$+13$

$+14$

$+15$

$+16$

$+17$

$+18$

$+19$

$+20$

$+21$

$+22$

$+23$

$+24$

$+25$

$+26$

$+27$

$+28$

$+29$

$+30$

Place Arrow

And +1 on the $\boldsymbol{\gamma}+3$

value below +5

half. $\quad+7$

$+9$

$+11$

$+13$

$+15$

$+17$

$+19$

$+21$

$+23$

$+25$

$+27$

$+29$

$+31$

$+33$

$+35$

$+37$

$+39$

$+41$

$+43$

$+45$

$+47$

$+49$

$+51$

$+53$

$+55$

$+57$

$+59$

$+61$

CUT OUT SCALES ALONG DARK LINES 
Instructions to Worksheets

The instructions are divided into four parts plus an introduction. The intent is to progress the user through the worksheets in small manageable steps. The instructions follow:

Forecasting Instructions

Introduction: The purpose of this sales forecasting kit is to assist you in preparing a sales forecast for the short term, specifically, one to twelve months. Three techniques are used in combination to produce the best possible outcome. The methods are time series, where seasonal and trend factors are included, operational, where day to day figures are used to predict sales and lastly, a judgmental forecast where your understanding of the general situation is taken into consideration. These worksheets are designed for use with a basic calculator. If you have a programmable calculator all the better. In that case, several steps can be eliminated, saving you time.

Before starting, review your budget to actual sales performance, if the figures are close, your current technique may be quite acceptable. However, if there is a large variance, or you have no idea how to proceed in preparing a sales forecast for your budget, proceed directly to Step 1 . Read the 
directions carefully with the worksheets before you record the first number. Once this dry run is completed begin. Read the directions carefully.

\section{Part 1 Time Series Forecast}

Step 1. Decide for what level you're going to prepare a forecast (i.e.) ICM, Branch, Annex, or operating center, (i.e.) dining room, lounge, etc. Once you have decided the level, you're going to need not less than three years of monthly sales history. Take worksheet $I$ and list the 36 months of sales history in column 1 with their associated dates in the space provided to the left of column 1. Caution, be sure that you've only listed sales figures and round the figures to the nearest dollar. Now review the sales figures and note any very large or very small figures and try to find out what caused the variations.

Step 2. Add the first 12 sales figures and place that total in column 2 opposite the seven (7) listed to the left of column 1. Now using the spacing template provided, place it over column 1 so that the first figure is in the top window and the 13th figure is in the bottom window. Subtract the figure in the top window and add the figure in the bottom window to the first total you placed in colum 2. The resulting total is then placed below the first and the template is 
moved down one space and the process is repeated until you've reached the 36 th figure. As a quick check to see if all is right, add the last 12 figures in column 1 ; they should equal your last moving total. If they don't equal, begin over paying special attention to the spacing template.

Step 3. Divide the totals in colum 2 by 12 and record this average in column 3. This is a 12 month moving average of sales.

Step 4. Divide the figures in column 1 by the corresponding figures in column 3 and record the results in column 4. The results should be a percentage (i.e.) .97 1.05 etc. Only use two decimal places. Ignore the first 6 figures in column 1. These percentages are the seasonal index numbers that represent that months sales as a percentage of the current annual average at that point in time.

Step 5. Now turn to worksheet 2. You will note the boxed space labeled Seasonal Index. Record the index numbers under their appropriate month and $\mathrm{fill}$ in the appropriate year. Once all of the figures in column 4 are transferred, average the index numbers. This average is your current seasonal index for each month expressed as a percentage of the current annual average. If you wish a graph of the seasonal curve, it 
can be plotted in the space provided. Now, as a manager you have a precise picture of the seasonal effects on sales. You may wish to stop here, although it's not recommended. To prepare a forecast at this point, simply multiply the index number for each month by the current annual average, which is the last figure in column 3.

Note: Additional spaces have been provided for continuous update as time progresses up to five years.

Step 6. Return to worksheet 1. Next you will be computing a straight line that will represent your current sales trend. Read the following carefully: You have a choice between a 25 point moving average base which is all of the figures in column 3 or a 12 point moving average base which is the last 12 figures in column 3 irom which to compute the trend line. The question is which one to use? The following is a test to determine just that:

1. Average all of the values listed in column 3 and record it here

2. Next average the last 12 values in column 3 and record it here

3. Now read the current annual average (CAA) here - It's the last figure in column 3 . 
4. Subtract the average recorded in item 1 from the current annual average ( $C A A)$ and record it here_._. Also, subtract the average recorded in item 2 from the CAA and record it here Now compare the two. The smallest number indicates which base to use for the trend calculations. It is also a judgment call on your part. If the 12 point base produces the smallest number then there is a $70 \%$ probability that this base will provide a more accurate trend. More importantly, it saves time. The judgmental aspect is whether or not you're willing to accept a $30 \%$ probability that the 12 point base is not the most accurate, in order to save time. Check Your Choice

12 point trend base. 25 point trenà base.

Step 7. Look at column 5 on worksheet 1 . The coding referred to is a process to eliminate large numbers. You will be 
working with the figures in column 3 based upon your choice in step 6. If the figure in column 3 are 6 digits (i.e.) \#265,792 divide by 1000 resulting in a much more manageable number of 265.7 or 265.8. The same applies for 4 or 3 digit numbers where you may want to code by dividing by 100 (i.e.) 579257.9 or $792 \quad 7.9$ one decimal place is enough. Based upon your coding choice, check the appropriate box at the top of column 5 .

Step 8. This step is very important so read carefully. Let's assume that your choice in step 6 was the 12 point base. From column 3 take the last 12 moving averages and code them as explained in step 7 and list them in column 6. Be sure to list their corresponding dates in column 5. As part of your kit you will find two $X$ VALUE SCALES. One for an even number of values and one for an odd number of values. Now that the coded moving averages have been listed in column 6 , select the appropriate X VALUE SCALE. In this case (i.e.) the 12 point base, you would select the even scale. Place the even $X$ VAIUE SCAIE over column 5 so that you can read the consecutive numbers 1-60. Align the arrow on the X VALUE SCALE with the number below half, in this case 6 is half, 7 is where the arrow should be aligned. If the odd number scale is 
appropriate, the arrow would be aligned with the center value. Tape or hold firmly the X VALUE SCALE in place.

Note: You may wish to record the figures obtained in

Steps 9 and 10 in light pencil because each

time the trend line is recomputed these

figures will change.

Step 9. To obtain the figures for column 7, multiply the $X$ VALUE SCALE figures by the coded moving averages in column 6 . Remember these basic rules: When multiplying two signed numbers, if the signs are the same the product will be positive. When multiplying two signed numbers, if the signs of the numbers are different, the product will be negative.

Step 10. To calculate the figures for column 8, square the $X$ VALUES, following the rules in step 9, all of these figures will be positive.

Step 11. Turn to worksheet 2 and look at the bottom half of the page where it is labeled TREND WORK SPACE. These equations are for the straight line that will describe your sales trend. The $Y_{F}$ is the forecasted value. "a" is the $y$ intercept or where the trend Iine crosses the $y$ axis of a graph and "g" is the slope of the trend line, it may be positive or negative. 
To calculate "a" simply average column 6 and place that value under the "a" in the box labeled YOUR TREND EQUATION. NOw, for "b" , sum column 7 and divide it by the sum of column 8 and place this number under the "b" space. Now to fill in the $(X)$ column in the equation, you will have to return to worksheet 1 and the $X$ VALUE SCALE. First note the date that corresponds to the last value in column 6. From that date count through the calendar to the first date (Month) for which you want to forecast and check the corresponding $\mathrm{x}$ value for that date (Month) on the $X$ VALUE SCALE. This $X$ VALUE SCALE figure is the first figure you will place under the (X) in the trend equation on worksheet 2; also record the month and year in the space provided. Repeat this process until you have recorded an $(X)$ value for each of the forecast months. Do not exceed 12 points. For best results use a quarter ( 3 months). Now to calculate $\underline{V}_{F}$ multiply " $b$ " times $(X)$ and add the "a" value. Remember " $a$ " and " $b$ " stay the same for the initial forecast calculations. If, by chance, "b" is negative then the $b(X)$ figure will be negative. Remember this basic rule: Subtract the numerical values and use the sign of the largest number.

Step 12. At the bottom of worksheet 2 under the title SALES 
FORECAST you will now prepare your sales forecast based on the TREND FORECAST and SEASONAL INDEX. Transfer the dates and $Y_{F}$ values obtained through the trend equation. From the top of worksheet 2, record the corresponding seasonal index for the months to be forecasted. Now multiply the TREND times the SEASONAL INDEX and you have it. Uncode the figures by multiplying by $(x 100)$ or $(x 1000)$, depending upon your coding choice checked at the top of column 5, worksheet 1. Comments: This statistically based forecast is the best one to use when preparing the annual budget. The operational forecast which follows should be used for each quarter. However, the last forecast (i.e.) the judgmental forecast, also must be considered in preparation of the annual and quarterly forecasts. As each successive month passes you will need to up date this system. As this takes place record the sales figures in column 7 and simply, continue the process in Steps 1 through 5. As additional seasonal Index figures are included, continue to up date with new averages.

It is not necessary to recompute a new trend equation each month, each quarter is quite adequate.

\section{Part II Operational Forecast}

Food Sales Forecast

Step 1. Begin with worksheet 3. Fill in the blanks for 
General Sales Mix, and General Beverage Sales Mix.

Step 2. Complete the section labeled Meal Period Sales Analysis.

Step 3. From the data obtained in Steps 1 \& 2 you can complete the meal period forecasts which ends with Dinner at the top of worksheet 4 .

Beverage Sales Forecast. (Worksheet 4 ).

Step 1. Complete by filling in the blanks for the section entitled Beverage Sales Analysis.

Step 2. Prepare the Beverage Sales Forecast for each operating Lounge/Bar in the space provided.

Completing $\underline{\text { F }} \underline{\mathrm{B}}$ Forecast.

Step 1. Consolidate and total Beverage and Food Forecasts and list in spaces provided.

Step 2. Compare the Food and Beverage Forecast with the statistical forecast transcribed from worksheet 2. At this point just compare, do not make any adjustments. In the space provided make any notes or comments that come to mind concerning 


\section{differences.}

Part III Judgmental Forecast Worksheet 5

Step 1. Read each question carefully, research it and answer it the best you can. One suggested method is to pose them to your staff, associates, the primary staff officers of the installations or anyone that may be able to provide meaningful input.

Step 2. In as many instances as possible, calculate the impact of any given situation. These should be addressed as a percentage increase or decrease in one of the objectively based forecast (i.e.) statistical or operational.

Step 3. The final step is to apply these judgmental adjustments to the Total Forecast.

\section{Part IV Final Forecast \& Evaluation Worksheet 6}

Step 1. At the top of worksheet 6 , note that you now have all three forecasts. Each should be compared and the final forecast prepared.

Step 2. As actual sales are recorded, complete the forecast 
evaluation segment of worksheet 6 . Four measures are provided for evaluating the accuracy of your forecasts. The first is the basic error, that is the actual sales minus the forecasted sales. This may be a positive or negative number depending on the direction of the error. The second measure is the Percentage Error, which is calculated by dividing the error by the actual sales (i.e.) Actual-Forecasted Sales divided by Actual Sales. Again, this may be a positive or negative percentage for the same reason as mentioned above. The third measure is the Error Squared, which is simply the error times itself. This eliminates all negative values. The last measure is the Mean Error Squared, which is the average of the Error Squared values.

The smaller the error the better the forecast and this rule holds for all four measures. From this evaluation, the relative accuracy of your forecast can be measured and from this you can adjust the techniques as you see fit.

Forecasting Packet Contents

The composition of the actual forecast packet must provide the manager with adequate flexibility to insure continued use. As a minimum, the following composition is proposed: 


\begin{tabular}{lc} 
Instructions & 1 set \\
Worksheet 1 & 2 each \\
Worksheet 2 & 2 each \\
Worksheet $3 \& 4$ & 8 each \\
Worksheet 5 & 12 each \\
Worksheet 6 & 2 each \\
Spacing Template & 1 each \\
X VALUE SCALES (2) & 1 each \\
\hline
\end{tabular}

Obviously, as the system is refined, this distribution will be adjusted. Iikewise, photocopying will provide additional flexibility for the using manager. 
VI. SUMMARY AND RECOMMENDATIONS 


\section{Summary}

The accuracy of these methods are proven through their general acceptance in the business community. Cbviously, these are very basic, however, in the absence of an established method, these can provide the basis for further development. Furthermore, when clubs obtain dedicated computer systems, a more sophisticated approach can be installed.

Several factors are worth mentioning conceming the data analysis. The primary hypothesis of this study was supported. Attention must be given to the seasonal aspects of club sales because, as shown, each operating unit has a unique seasonal curve. Furthermore, the differences between the officers and NOC/enlisted operations must be kept in mind when system wide decisions are being made. Likewise, constant attention must be given to the sales trends. As mentioned, the cyclical factor should be subjected to further study and included in the system when data processing facilities are available.

\section{Recommendations}

Bevond the satisfaction of the academic requirement, it is the intention of the author to forward a copy of this study to the Director of the U.S. Army Club and Community 
Activities Directorate, Washington D.C. for his consideration for adoption by the Army Club System.

It is recommended that the two templates, that are part of the packet, be produced on clear plastic and that special care be taken to insure proper spacing for alignment with Worksheet 1 . It is further recommended that the worksheets be type set and printed to insure the spacing integrity. 


\section{BIBLIOGRA PHY}

Bolhuis, John L. and Wolff, Roger K. The Financial Ingredient in Foodservice Management. Lexington, Massachusetts : D. C. Heath and Company, 1976 .

Brodner, Joseph; Carlson, Howard M.; and Maschal, Henry $T$. Profitable Food and Beverage operation. Fourth Edition. Rochelle Park, New Jersey: Hayden Book Company, Inc., 1962.

Coltman, Michael M. Hospitality Management Accounting. Boston, Massachusetts: CBI Publishing Company, Inc., 1978.

Eby, Frank H. Jr. and $\mathrm{O}^{\prime} \mathrm{Ne} i \mathrm{ll}$, William J. The Management of Sales Forecasting. Lexington, Massachusetts: Lexington Books, 1977 .

Fay, Clifford T.; Rhoads, Richard C.; and Rosenblatt, Robert L. Managerial Accounting for the Hospitality Service Industries. Second Edition. Dubuque, Iowa: Wm. C. Brown Company Publishers, 1976.

Gilchrist, Warren. Statistical Forecasting. New York, New York: John Wiley \& Sons, 1976.

Hamburg, Morris. Statistical Analys is for Decision Making. Second Edition. New York, New York: Harcourt Brace Jovanovich, Inc., 1977.

Heyel, Carl (ed.). The Encyclopedia of Management. Second Edition. New York, New York: Van Nostrand Reinhold Company, 1973.

Keiser, James and Kallio, Elmer. Controlling and Analyzing Costs in Food Service operations. New York, New York: John wiley \& Sons, Inc., 1974.

Koontz, Harold and O'Donnell, Cyril. Principles of Management: An Analysis of Managerial Functions. Fourth Edition. New York, New York: McGraw-Hill Book Company, 1972.

Lippitt, Vernon G. Statistical Sales Forecasting. New York, New York: Financial Executive Research Foundation, 1969. 
McCarthy, Jerome E. Basic Marketing a Managerial Approach. Fourth Edition. Homewood, Illinois: Richard D. Irwin, Inc., 1971.

Montgomery, Douglas C. and Johnson, Lynwood A. Forecasting and Time Series Analysis. New York, New York: McGraw-Hill Book Company, 1976.

Murdick, Robert G. and Schaefer, Arthur E. Sales Forecasting for Lower Cost and Higher Profits. Englewood Clifts, New Jersey: Prentice-Hall Inc., 1973.

Richard, Robert S. Practical Techniques of Sales Forecasting. New York, New York: McGraw-Hill Book Company, 1966.

Sartorius, Lester $C$. and Mohn, N. Carroll. Sales Forecasting Models: A Diagnostic Approach. Atlanta, Georgia: Publishing sêrvice Div. College of Business Administration, Georgia State University, 1976.

Schoner, Bertram and Uhl, Kenneth P. Marketing Research Information Systems and Decision Making. Second Edition. New York, New York: John Wiley \& Sons, Inc., 1975.

Wheelwright, Steven C. and Makridakis, Spyros. Forecasting Methods for Management. New York, New York: John Wiley \& Sons, 1973. 